\title{
SURFACE RIGHTS ACQUISITION AND COMPENSATION
}

\author{
WILLIAM N. RICHARDS* and FRANCIS C.R. PRICE*
}

\begin{abstract}
This paper reviews the various interests in land which the resource industry may acquire from the Crown and freehold owners and the right of the industry to expropriate such interests in Alberta, British Columbia, Saskatchewan and under the federal legislation. There follows an analysis of the principles and methods of determining compensation for such expropriated rights, particularly in light of recent judicial decisions. Finally the authors consider the new developments which may arise as a result of pro. posals to amend the federal National Energy Board Act and the possible recommendations of the Select Legislative Committee on Surface Rights in Alberta **
\end{abstract}

\section{ACQUISITION BY NEGOTIATION}

\section{A. Crown Lands}

That Her Majesty the Queen in Right of the Province of Alberta has the authority to dispose of Crown Lands for the purpose of the resource industry is clear. ${ }^{\prime}$ The types of interest which may be acquired appear to be sufficient to meet the needs of the industry. An outright purchase is possible. Other interests which may be acquired include: agreements permitting the installation of a pipeline; agreements permitting surface installations used in connection with a pipeline such as meter sites, clean-out traps or the like; mineral surface lease agreements for use as access to a well drilling site; licences of occupation permitting the occupation of the land for various purposes such as access roadways; surface materials leases permitting the removal of sand, gravel or other material; easements; and various miscellaneous leases.

It is possible to negotiate a fee simple title to the land upon which a gas plant is to be constructed, and this appears to be most desirable given the heavy economic commitment required for the building of such plants. ${ }^{2}$ The Department of Energy and Natural Resources, however, is not as quick to grant a fee simple interest for railway rights of way to and from such plant sites and resource companies are requested to live with a licence of occupation for such purposes. This is less than satisfactory given the informality of such an agreement and the uncertainty created by it, and given the high financial outlay involved in building a railway line. It might be possible to get the railway company to expropriate for such an interest in these circumstances, but the resource company lacks that ability. ${ }^{3}$

There are three basic problems in dealing with the Crown. The first and most frustrating one is the delay which is invariably encountered when attempting to negotiate for the acquisition of an interest in the surface of Crown land. The second is the type and number of conditions which the

- Partners, Reynolds, Mirth \& Côté, Edmonton.

* EDITOR'S NOTE: Since the cases discussed in this article span several decades, the reader should note that effective June 30,1979 , the District Court and the Supreme Court Trial Division were merged into the Court of Queen's Bench, and the Supreme Court Appellate Division became the Court of Appeal of Alberta.

1. The Public Lands Act, R.S.A. 1970, c. 297, ss. 9, 10 and 20, as am..

2. But the Minister may require that the land revert to the Crown in the event it is no longer required for such purposes: $I d$, s. 21(1K(b).

3. However, such right must be expressly given. The Interpretation Act, 1980, S.A.1980, c. 70, s. 14. 
Crown often imposes when it does grant an interest in land. These include the following: contact the local Forest Superintendent; minimize the disturbance to the environment as directed by officers of the Minister; backfill, establish vegetation, cleanup and dispose of debris as directed by an officer of the Minister; utilize existing lines, install culverts, etc.; salvage merchantable timber; and comply with the Department of Environment requirements on major water crossings. The third problem is that the interest granted under the various forms of agreement from the Crown often leaves much to be desired. For example, the licence of occupation granted by the Crown likely does not amount to an interest in the land. Thus a valid caveat cannot be registered at the Land Titles Office. ${ }^{4}$ This becomes important in situations where the Crown has granted a title to a homesteader or other person subsequent to the granting of a licence of occupation to a resource owner. The resource owner might find itself in a position of having to re-negotiate with the homestead purchaser or other person receiving a transfer as it is not able to file a caveat to protect its interest under a licence of occupation. Such circumstances often lead to the resource owner being forced to pay double compensation.

Of course in circumstances where the Crown has made other dispositions of the land which affect the rights applied for by the resource owner, it will be necessary for the resource owner to obtain the consent of or otherwise enter into some agreement with those also having an interest. A form of consent to mineral surface leases or pipeline agreements is provided by the Department of Energy and Natural Resources to be used where there is a grazing occupant or homestead purchaser. It provides that the homestead purchaser or grazing lessee is entitled to compensation to the extent that such person's interest is affected by the mineral surface lease or pipeline agreement.

\section{B. Other Govermmental or Quasi Governmental Bodies and Special Circumstances}

Dealing with a municipality is like dealing with an individual except that the matter must go before the Council of the municipality for approval. ${ }^{5}$ Although municipalities have the authority to grant the types of interest in their land which resource companies require, the delay involved in getting an agreement often makes the most expedient course of action expropriation (subject to the limitations discussed in part III below). It then becomes necessary to negotiate the price to be paid for the interest taken, the appropriate agreement and also the eventual abandonment of the expropriation proceedings.

The Department of Municipal Affairs administers certain special areas such as the drought belt in Southern Alberta ${ }^{6}$ and dealing in that area has a procedure all its own. A consent of occupant is first taken; then a mineral surface lease is acquired from the Special Areas Office in Hanna, Alberta.

Metis Settlement areas create special problems. Taking a surface interest in Metis land in the Province of Alberta is fraught with legal difficulties. The rights are held in some fashion by a number of groups, including the Minister designated in charge of the administration of the

4. The Land Titles Act, R.S.A. 1970, c. 198, s. 136, as am..

5. The Municipal Government Act, R.S.A. 1970, c. 246, s. 128(1), as am.

6. The Special Areas Act, R.S.A. 1970, c. 349, as am.. 
Act, ${ }^{7}$ the Settlement Association and the individual Metis settlers for whose benefit the land has been set aside. To add to the confusion, there are law suits continuing with respect to the ownership of mines and minerals within, upon or under the lands set aside for the use of the Metis, ${ }^{8}$ and the outcome of those actions could well affect the authority of the Metis and the Crown with respect to their power to grant dispositions of the surface to resource companies. As a result of this confusion, the only prudent course of conduct when dealing with Metis settlement lands is to proceed with expropriation and obtain a board order for the interest required in order to ensure that the proper legal rights are obtained. Furthermore, it is often unclear whether the road allowances within Metis settlements, particularly the unsurveyed ones, are in fact part of the settlement lands or are reserved out of the grant of settlement lands. To determine this it is necessary to examine the Regulations setting aside the land for the Metis settlement to see whether the road allowances which have been unsurveyed appear to be included. Often they are not, and to cover the unsurveyed road allowances it is important to join Her Majesty the Queen in Right of the Province of Alberta as represented by the Minister of Energy and Natural Resources to any application under The Surface Rights Act for right of entry in Metis settlement lands. Again, it may be possible to agree with the various persons interested as to the amount of compensation payable when such rights are taken, and the Surface Rights Board will generally go along with those agreed amounts of compensation and make them part of a compensation order. ${ }^{9}$ Such an order should be obtained to avoid any possible future claim that the resource company paid the compensation to the wrong party.

Indian reserves, of course, come under the control of the federal government. ${ }^{10}$ This necessitates dealing with the Department of Indian Affairs and Northern Development in conjunction with a Band Council. The Indian bands have been known to exact unusual conditions for granting rights of entry, such as having the right to do some of the clearing and site preparation work on the locations. There seems little doubt that the provincial legislation relating to right of entry would have no effect on Indian lands, and thus successful negotiation with the Indian bands and the federal government is essential. There is a common interest where Indians also own the mines and minerals, because to receive the royalty revenue it will be necessary for them to permit disposition of the surface rights in order that the petroleum substances can be retrieved. However there are certain instances in which a resource company requires a portion of the surface of Indian lands to obtain access to mines and minerals which are not Indian owned, and in such cases the right to expropriate Indian lands does not exist.

When planning the location of pipeline rights of way, in particular in areas where the surface is extremely valuable such as near large population centres, it is important to keep in mind that it may be possible to negotiate with the owners of railway lines, power lines and other pipelines, to have the new pipeline located, at substantial savings, in the

7. T'he Metis Betterment Act, R.S.A. 1970, c. 233, s. 2(b), as am..

8. See Queen's Bench Actions, Edmonton, 83520, 100945.

9. For example see Surface Rights decision E 36/81.

10. Indian Act, R.S.C. 1970, c. I-6, as am.. 
rights of way which have already been acquired. Such use fits in well with the pipeline corridor concept which seems to be popular with the environmentalists, although it might result in certain hazards. With respect to railway rights of way in particular, the result will be an easement in a piece of land for which quite possibly there has been no title created. It thus becomes impossible to register the easement in the Land Titles Office and the usual seeurity obtained by so doing is absent.

\section{Freehold}

There is no limit to the type of interest which a resource company may acquire from owners of lands for its purposes. Obtaining an interest voluntarily from the land owner may be quicker and cheaper than expropriating (not because less compensation is paid, but due to the fact that the costs of the hearing are avoided), and in any event some negotiation is required before an application for right of entry will be entertained by the Surface Rights Board. A voluntary grant for a pipeline can be obtained prior to receiving a permit to construct the line, but expropriation proceedings cannot be commenced until after a permit has been obtained from the Energy Resources Conservation Board.

Interests taken for access to, and the drilling of, oil and gas wells are usually protected by way of caveat in Alberta and Saskatchewan. However, in British Columbia, due to the different use of caveats under the British Columbia land titles system, ${ }^{1}$ such leases must be registered. This requirement means that more attention must be given to the form of the agreement to ensure that it is registrable. A registrable plan must accompany the surface lease.

Generally, one can obtain more rights under a negotiated easement or grant for a pipeline right of way (including the right to put in additional lines and to have above-surface equipment such as pumps, valves, clean out traps and poles). It may be that it is unnecessary to register an expropriation order under The Land Titles Act to obtain priority and indefeasiblity. Section 64(1) of that Act ${ }^{12}$ provides that the land mentioned in any certificate of title is, by implication and without special mention, subject to any right of way or easement granted or acquired under the provisions of any Act or law in force in the province.

It is important to remember that crossing agreements must be made where prior dispositions of the interests in favour of other members of the industry have been made. These agreements have grown more sophisticated than the simple letter agreements of ten years ago, now dealing with such matters as priority of interest, the requirement that notice be given before construction commences, specifications as to the installation, and the requirements that the grantee pay any costs incurred by the grantor and that the grantee indemnify the grantor.

It is often found desirable to purchase in fee simple regulator station sites or meter sites to be used in connection with a pipeline. Such titles can be obtained without obtaining planning approval, ${ }^{13}$ but a registrable survey plan is usually necessary.

11. Caveats lapse automatically after 60 days: Thom's Canadian Torrens System (2nd ed. Di Castri, ed.) 638.

12. The Land Titles Act, supra n. 4.

13. The Planning Act, 1977, S.A. 1977 c. 89 , s. 3(c), as am.. 
"Foreign controlled corporations" have difficulty acquiring interests in "controlled land" due to The Agricultural and Recreational Land Ownership Act 14 and the Regulations passed pursuant to it. The restrictions do not apply to Crown land ${ }^{15}$ and the Regulations contain exceptions for most interests required for the exploration of oil or natural gas. ${ }^{16}$

\section{ACQUISITION BY EXPROPRIATION}

\section{A. The Surface Rights Act}

At common law, ownership of mines and minerals included the right of access to them without compensating the owner of the surface. ${ }^{17}$ In Alberta, this was changed by statute effective July $1,1952 .{ }^{18}$ Similar legislation has been passed in Saskatchewan and British Columbia."

Under The Surface Rights Act an "operator" has the right to obtain an order to develop its resources. "Operator" means: ${ }^{20}$

(i) the person or unincorporated group of persons having the right to a mineral or the right to work the same, or the agent thereof, or (ii) with reference to a pipeline, power transmission line, or telephone line, the person empowered to acquire an interest in land for the purpose of the pipeline, power transmission line or telephone line under The Pipeline Act, 1975. The Hydro and Electric Energy Act or The Water, Gas, Electric and Telephone Companies Act. . . .

To establish that a person has a right to a mineral, ${ }^{21}$ the Surface Rights Board simply requires a statement in the application setting out such ownership and the person from whom a mineral operator acquired its interest. However, before an order is granted, the Board requires a copy of the well licence issued by the Energy Resources Conservation Board.

If an operator is applying to expropriate land for a pipeline, power transmission line or telephone line, the Board will require, before an application is entertained, the appropriate permit from the Energy Resources Conservation Board, or order from the Telephones Commission.

14. S.A. 1977, c. 1 , as am..

15. The Foreign Ownership of Land Regulations 160/79 as am.; O.C. 589/79; 0.C. 1159/79; s. 2(a). 589/79; 1159/79, s. 2(a).

16. The Agricultural and Recreational Land Ownership Act, supra n. 14, s. 8(1) and 0.C. $1159 / 79$.

17. Fuller v. Garneau (1921) 61 S.C.R. 450, Barber v. Shell [1923] 2 D.L.R. 1097 (S.C.C.), Borys v. C.P.R. (1953) 7 W.W.R. (N.S.) 546 at 559 (P.C.).

18. The Right of Entry Arbitration Act, S.A. 1952, c. 79, s. 10(2), now The Surface Rights Act, S.A. 1972, c. 91, s. 12(2) as am..

19. The Surface Rights Acquisition and Compensation Act, R.S.S. 1978, c. S-65, as am.; Petroleum and Natural Gas Act, R.S.B.C. 1979, c. 323.

20. The Surface Rights Act, supra n. 18, s. 1 (g).

21. "Minerals" means all naturally occurring minerals, and without restricting the generality of the foregoing, includes:

(i) gold, silver, uranium, platinum, pitchblende, radium, precious stones, copper, iron, tin, asbestos, salts, sulphur, petroleum, oil, zinc, asphalt, bituminous sands, oil sands, natural gas, coal, anhydrite, barite, bauxite, bentonite, diatomite, dolomite, epsomite, granite, gypsum, limestone, marble, mica, mirabilite, potash, quartz rock, rock phosphate, sandstone, serpentine, shale, slate, talc, thenardite, trona, volcanic ash, sand, gravel, clay and marl, but

(ii) does not include

(A) sand and gravel that belong to the owner of the surface of land under The Sand and Gravel Act, or

(B) clay and marl that belong to the owner of the surface of land under The Clay and Marl Act, or

(C) peat on the surface of land and peat obtained by stripping off the overburden, excavating from the surface or otherwise recovered by surface operations. 
One must look to the definition of "pipeline" as it is contained in The Pipeline Act, $1975^{22}$ to determine the extent of expropriation permitted pursuant to a permit granted thereunder. "Pipeline" means "a gas line, oil line, fluids line, multi-phase line, solids line, secondary line, distribution line, or flow line". ${ }^{23}$ Definitions are given for the types of lines encompassing "pipelines" in this legislation as well, and include "installations and connections therewith". "Installation" means: ${ }^{24}$

(i) any equipment, apparatus, mechanism, machinery or instrument incidental to the operation of a pipeline and (ii) any building or structure that houses or protects anything referred to in sub-clause (i) but does not include a refinery, processing plant, marketing plant or manufacturing plant.

Thus where land required for surface installations used in connection with a pipeline is subject to the right of an operator for expropriation, refineries such as gas plants are excluded, and the writers are not aware of any legislation permitting expropriation for such purposes.

Section 9(1) of The Hydro and Electric Energy Act ${ }^{25}$ makes it clear that an operator must hold a permit issued by the Energy Resources Conservation Board before expropriation may proceed for a transmission line pursuant to this legislation. Again "transmission line" as defined in the Act includes "... all property of any kind used for the purpose of, or in connection with, or incidental to the operation of a transmission line, but does not include a power plant or an electric distribution system". ${ }^{26}$

Under The Water, Gas, Electric and Telephone Companies Act (Water, Gas Act) no one shall install or erect wires or cables other than for the transmission of electricity until inter alia, plans have been approved by the Alberta Government Telephones Commission. ${ }^{27}$ Since the addition of s. 3.1 in 1971, the Water, Gas Act has not been applicable to transmission lines as defined in The Hydro and Electric Energy Act. Licensing of such transmission lines is now subject to The Hydro and Electric Energy Act with procedural rights under s. 29 of The Energy Resources Conservation Act. For transmission lines governed by the Water, Gas Act, by contrast, approval of the Minister must be obtained and procedural rights are those set out in s. 30(3) and s. 30(4) of the Water, Gas Act.

The Surface Rights Act contemplates expropriation of oil sands operations ${ }^{28}$ and use of adjoining land for directional drilling. ${ }^{29}$ In addition, expropriation for conservation schemes is also permitted. ${ }^{30}$

Once an application for right of entry has been filed, the operator must give notice of the application to those having an interest in the land which it requires to expropriate. ${ }^{31}$ The respondents have an opportunity to object to the application, and upon receiving such an objection, the Board may hold a hearing to determine whether the operator in fact requires or needs the interest for which it is applying in order to carry out its opera-

22. S.A. 1975 , c. 30 , as am..

23. Id, s.1 (22).

24. Id, s.1 (10).

25. S.A. 1971, c. 49, as am..

26. Id. s. $1(1)(14)(v)$.

27. R.S.A. 1970 , c. 387 , s.8.

28. Supra n. 18, s.12(3)(iii).

29. Id., s.12(4).

30. Id, s.13(1).

31. Id, s.15(3). 
tions, or whether the proposed location of the operator's interest is appropriate. ${ }^{32}$

It is disturbing to note that in certain circumstances an operator may be forced to be a party to two hearings dealing generally with the necessity for the pipeline or with its location or route. In addition to a land owner's right to object pursuant to The Surface Rights Act he is also entitled to a prior hearing under The Energy Resources Conservation Act ${ }^{33}$ before a pipeline permit is granted.

Although compensation is usually not in issue, it is helpful that provincial Crown land is subject to the Act, ${ }^{34}$ as often the procedure under the Act can be utilized to overcome delays, give a better legal interest than can be obtained by negotiation, or overcome onerous or unreasonable conditions to the use of the land which various government departments might seek to impose.

The Expropriation Act ${ }^{35}$ now only has relevance to expropriations made on behalf of the resource industry for power plants under The Hydro and Electric Energy Act $^{36}$ and works or undertakings under The Water Resources Act. ${ }^{37}$

\section{B. British Columbia Legislation}

Under the Petroleum and Natural Gas $\mathrm{Act}^{38}$ an operator may apply for right of entry, and after whatever mediation hearing the Board sees fit to hold ${ }^{39}$ the operator may receive a board order permitting the entry, use and occupation of the land. A security deposit is required and the Board may release it to the land owner..$^{40}$

Unlike Alberta, arbitrators under the Gas Utility Act," the Pipeline $\mathrm{Act}^{42}$ and the Railway $\mathrm{Act}^{43}$ are empowered only to determine the amount of compensation for easements taken. Under the Gas Utility Act the utility simply gives notice to the land owners of the area with a description of land required, the nature of the works to be constructed on it, the amount of compensation offered and generally a copy of the plan showing the land required (which is also filed with the Registrar of the appropriate Land Titles Office). ${ }^{44}$ The effect is to give the utility those rights claimed

32. Dome Petroleum Limited v. Swan Swanson Holding Ltd. (1970) 72 W.W.R. 6, at 12.13 (Alta. App. Div.); The Surface Rights Act, supra n. 18, s. 19(a). When the route is fixed under the permit, the only test is "reasonable necessity for the exercise of the rights within the near future or within a reasonable time": Alberta Power Limited v. Thiessen. S.R.B. decision 72-11: see also Re Union Gas and Quaggitto (1974) 41 D.L.R. (3d) 515 (Ont. C.A.).

33. S.A.1971, c. 30, s. 29(2). But see Calgary Power Ltd. v. Henkel(1976) 10 L.C.R. 136 (Alta. App. Div.), where s. 9 of The Expropriation Act (S.A. 1974, c. 27, as am.) was applied to dispense with the later hearing under The Expropriation Act.

34. The Surface Rights Act, supra n. 18, s. 15(1).

35. S.A. 1974, c. 27, as am. S.A. 1976, c. 85.

36. S.A. 1971, c. 49.

37. R.S.A. 1970 , c. 388 , as am. S.A. 1975 , c. 88.

38. Supra n. 19, s. 16(1).

39. Id. s. 18.

40. Id, s. 19.

41. R.S.B.C. 1979 , c. 150.

42. R.S.B.C. 1979 , c. 328.

43. R.S.B.C. 1979 , c. 354 .

44. Gas Utility Act, supra n. 41, s. 8. 
in the land. ${ }^{45}$ In practice, however, gas utilities apparently expropriate under the Pipeline Act, rather than the Gas Utility Act. ${ }^{48}$

The expropriation procedures contained in the Railway Act are incorporated by reference in the Pipeline Act for expropriations for pipelines, ${ }^{47}$ while the procedure contained in the Petroleum and Natural Gas Act relating to expropriation is incorporated for flow lines. Under the Railway Act, the expropriation procedure begins when the pipeline company deposits its plan, profile and book of reference, approved by the Minister of Transport and Communication under section 11 of the Pipeline Act, in the proper land registry office. Again, expropriation is effected simply by notifying the owner of the land and declaring readiness to pay a sum certain as compensation..$^{48}$ Pursuant to s. 71 of the Railway Act, the company only has the right to take possession of the expropriated land when it has made payment of the compensation awarded or has paid the same into Court pursuant to s. 67. However, ss. 73 and 74 provide a procedure for immediate possession of the land. The company must satisfy the judge to whom it applies that immediate possession of the right of way is necessary to carry out the operations which the company is presently ready to undertake. Under s. 74(b), security must be paid into Court sufficient to cover the judge's estimate of the compensation payable and costs, and at least half as much again as the amount offered by way of compensation. Once a judge grants the warrant, the company begins construction, and the compensation remains to be agreed upon or to be determined by an arbitrator.

\section{Saskatchewan Legislation}

The purposes of The Surface Rights Acquisition and Compensation Act ${ }^{49}$ are to provide for a comprehensive procedure for acquiring surface rights, to provide for the payment of just and equitable compensation for the acquisition of surface rights and to provide for the maintenance and reclamation of the surface of land required in connection with the surface rights acquired under the Act. ${ }^{50}$ The Act adopts most of the recommendations contained in the Friesen Report. ${ }^{51}$

The Act provides that an operator does not obtain any surface rights that may be contained in a petroleum and natural gas lease unless the said lease provides a specific separate consideration for such rights in accordance with the provisions of the Act. The Act does not apply to any surface rights that have been exercised prior to the coming into force of the Act, but provides that any rights that have not been exercised by the operator may only be exercised in accordance with the provisions of the Act, unless the owner and occupant, if any, agree otherwise in writing

45. Id., s. 9(1).

46. F.C.R. Price. Pipelines in Western Canada - Construction Permits and The Acquisition of Land, 1975, p. 129.

47. Pipeline Act, supra n. 42, s. 16.

48. Railway Act, supra n. 43, s. 50.

49. Supra n. 19.

50. Id., s. 3.

51. The Report of the Royal Commission on Surface Rights and Pipeline Contracts, November, 1966, Judge J.E. Friesen, Commissioner - one exception is that the acquisition of and compensation for pipeline easements are not included in the Act: Chapter 15. 13-18. 
with the operator by a separate instrument made after the coming into force of the Act. ${ }^{2}$

The Act applies to the acquisition by the operator of: ${ }^{53}$

(a) the right to enter upon the land for the purpose of drilling for a mineral;

(b) land for a well-site and roadway;

(c) the right to enter upon, use, occupy or take land for the purpose of constructing a power line; and

(d) land for a battery site.

The Act also applies to the acquisition of certain rights that are required by an operator in respect of the surface of land outside the wellsite, battery site and roadway. These include the following: $:^{54}$

(a) the right of entry upon lands lying upon the intended route of a flow line or service line for the purpose of making surveys, examination and other necessary arrangements for fixing the site of the right of way for such lines;

(b) the right to enter upon, use, occupy or take land or an interest therein for the purpose of laying, constructing, maintaining and repairing a flow line or service line.

An owner has the right to object to the Board issuing an order granting an operator immediate right of entry, and in this event the Board is required to hold a hearing to determine whether or not it should issue such an order. ${ }^{55}$ All such applications include information with respect to the compensation offered and requested. ${ }^{56}$ The determination of such compensation may be deferred..$^{57}$

The operator is required to provide a security deposit, or bond in lieu thereof, and advance payments can be made to the owner from the security deposit, or in the event that a bond has been posted, the operator may be required to make advance payments if so directed by the Board..$^{58}$

The Act applies to land owned by the Crown. ${ }^{59}$ The Act covers adjacent land that the operator may require. ${ }^{60}$ Any voluntary agreement between an operator and an owner made with respect to compensation for any surface right is required to be filed with the Board within thirty days of the execution thereof. ${ }^{61}$ Compensation is to be paid to both the owner and the occupant, but there is to be no duplicate compensation. ${ }^{62}$

The Board has jurisdiction to deal with off right of way damage, and other tortious acts, but there are strict time limitations put on any owner making such a claim..$^{63}$ The Act contains provisions for mediation, but to be effective, both parties must agree with the mediation officer's report. ${ }^{64}$

52. The Surface Rights Acquisition and Compensation Act supra n. 19, s. 6.

53. Id. s. 23.

54. Id. s. 41.

55. Id, s. 31(7).

56. Id., s. $31(2)(\mathrm{b})(\mathrm{c})$.

57. Id, s. 33(3).

58. Id., ss. 36, 49 .

59. Id., s. 25.

60. Id. s. 27.

61. Id, s. 30 .

62. Id. ss. 35,48 .

63. Id. ss. 60-64. Compare with s. 38 of The Surface Rights Act, supra n. 18.

64. Id. ss. 65-70. The procedure is quite different from the mediation contemplated under the British Columbia legislation: Petroleum and Natural Gas Act, supra no. 19, s. 18. 
The provisions of The Expropriation Procedure $\mathrm{Act}^{65}$ and The Pipelines Act ${ }^{68}$ make it clear that the only issue to be determined between the parties on the expropriation for a pipeline is the amount of compensation payable, but a person with an interest in the land has a right to apply to the Public and Private Rights Board for a review of the "route, situation or design" of the pipeline.

Under The Expropriation Procedure Act, an operator files a Notice of Possession in the appropriate Land Titles Office and immediately possession is taken. ${ }^{88}$ Within one year of possession, the company must file a Declaration of Expropriation and a plan of survey in accordance with s. 10 of The Expropriation Procedure Act. The interest in land vests in the expropriating authority upon the filing of the Declaration of Expropriation. The Declaration of Expropriation requires no confirmation, nor is there any requirement for any other form of approval of the expropriation. All that remains to be determined is compensation payable to the parties affected by the expropriation.

\section{Rental Review}

It is interesting to compare the rental provisions in existence in Alberta ${ }^{69}$ Saskatchewan ${ }^{70}$ and British Columbia. ${ }^{11}$

The Alberta legislation applies only to compensation orders or surface leases entered into after January 1, 1972. Retroactive legislation has been threatened, but, because the industry has undertaken to "voluntarily review" prior board orders and surface leases, such legislation has not been implemented. Generally the companies renegotiate the annual rental payable under the pre-1972 arrangements, and enter into amending agreements with the land owners which provide for the increased rental, with a review at the end of each succeeding five-year period. The agreements provide that the matter will be settled by the Surface Rights Board, if the parties are unable to agree on the new rate of compensation. However, the Surface Rights Board has taken the view that unless a new agreement has been entered into (dated on or after January 1,1972 ) it has no jurisdiction to deal with the matter, and accordingly land owners have been frustrated in their attempts to seek a level of compensation greater than that offered by the operator.

For the post-1971 situation, the Alberta legislation provides that either party may give notice at any time after four years has elapsed since the date of the order, lease or last review, and negotiations are then entered into with a view to determining the right of compensation for the next five years. If agreement is not reached, the Board will determine compensation.

Under the Saskatchewan legislation, unfortunate time limitations exist. The notice for review must be given within the period commencing three months before the fifth anniversary of a lease or order, and ending

65. R.S.S. 1978, c. E-16.

66. R.S.S. 1978, c. P.12.

67. The Expropriation Procedure Act, supra n. 65, s. 7(1).

68. Id., s. 11.

69. The Surface Rights Act, supra n. 18, ss. 36, 37.

70. The Surface Rights Acquisition and Compensation Act, supra n. 19, ss. 38-40.

71. Petroleum and Natural Gas Act, supra n. 19, s. 11. 
three months thereafter. The legislation does have retroactive effect, however, and applies to any lease or order whenever made.

The British Columbia legislation has similar retroactive effect; the notice period is longer, but still limited to one year. Notice must be given during the fifth year (or each successive fifth year) from the date of lease or order.

\section{E. Federal Pipeline Expropriations}

Inter-provincial pipelines are governed by federal legislation and provincial expropriation legislation cannot affect such undertakings. ${ }^{72}$. Once a pipeline extends beyond a boundary of a single province it comes under the control of the National Energy Board.$^{73}$ No construction may commence until a certificate of public convenience and necessity has been granted by the National Energy Board. ${ }^{74}$ Once this certificate has been issued the company must submit to the Board for its approval a plan, profile and book of reference of the pipeline and must file the approved documents in the Land Titles Offices of the districts through which the pipeline will pass. The provisions of the Railway Act dealing with, inter alia, the right to expropriate are incorporated by reference and govern the procedure to be followed. ${ }^{75}$

The filing of the plan, profile and book of reference is deemed to be notice that the land will be required for pipeline purposes, ${ }^{76}$ and the company is required to give notice to the land owner of the description of the lands taken and the amount of compensation offered. ${ }^{77}$ That the amount of compensation offered is fair must be sworn to by an independent surveyor or engineer, ${ }^{78}$ and if the compensation is not accepted the amount of compensation is determined by a County Court or Superior Court judge (as arbitrator) for the district or place where the lands lie. ${ }^{79}$ No particular guidelines are offered to the judge as to how such compensation is to be determined, and costs are in the discretion of the judge. ${ }^{80}$ The right to possession exists upon payment or tender of the compensation, ${ }^{81}$ but the company may in appropriate circumstances obtain a warrant for immediate possession without waiting for a compensation hearing. ${ }^{82}$

\section{CONCURRENT RIGHTS TO EXPROPRIATE}

An interesting question is whether one expropriating authority has the right to expropriate an interest in land which is held by another body also

72. Dome Petroleum Ltd. et. al v.Swan Swanson Holdings Ltd. [1971]2 W.W.R. 506 at 512 (Alta. App. Div.).

73. National Energy Board Act, R.S.C. 1970, c. N-6, s. 9-2., as am..

74. Id, s. 27.

75. Id, s. 75. See the reference to the anachronistic provisions of the Railway Act in Cochin Pipelines Ltd v. Rattray [1981] 1 W.W.R. 732 at 734 (Alta. C.A.).

76. Railway Act. R.S.C. 1970, c.R-2, s. 154, as am..

77. Id. s. 156.

78. Id, s. 157.

79. Id. s. 160. See Cochin Pipelines Ltd. v. Rattray [1979] 6 W.W.R. 755 (Stevenson J. as arbitrator).

80. Id., s. 164.

81. Id, s. 179.

82. Id., s. 181 . 
having the right to expropriate. Due to the doctrine of federal paramountcy, there appears to be no doubt that an inter-provincial pipeline cannot be affected by the right to expropriate for a purely local one. ${ }^{83}$

It is the practice of the Surface Rights Board to grant to a subsequent operator the concurrent right to use, for example, land for a roadway which has already been acquired by an operator. The Board will in such circumstances award compensation to the first operator where it has made improvement, such as the construction of a road, and which is to the benefit of a subsequent operator. That the Board has the authority to make such joint orders can be inferred from s. 22(2) of the Act, ${ }^{84}$ which provides that even a non-operator may apply to the Board for the joint use of lands held by an operator.

There is authority for the proposition that an interest, which is of itself capable of being created by expropriation, cannot be expropriated, ${ }^{85}$ particularly where the prior interest in the land was created by expropriation.$^{86}$ This appears to be the case unless there is express or implied provision in the expropriation legislation to the contrary. ${ }^{87}$

However, where land is owned by one body with powers of expropriation and is not essential to the undertaking of that body, or is not being used by that body, it may be subject to expropriation. ${ }^{88}$ The Alberta Supreme Court Appellate Division has gore farther and held that a subsequent application for expropriation could exceed and affect similar rights acquired by earlier expropriation by an expropriating authority subject to provincial legislation. ${ }^{89}$ No authority was cited for this proposition.

\section{ASSESSMENT OF COMPENSATION IN ALBERTA}

In Alberta, compensation for the expropriated owner's interest in the land and damages is determined under s. 23 of The Surface Rights Act. ${ }^{90}$ In particular, s. 23(2) provides: ${ }^{90 \mathrm{a}}$

(2) The Board, in determining pursuant to subsection (1) the amount of compensation payable, may consider

(a) the value of the land.

(b) the loss of use by the owner or occupant of the area granted to the operator,

(c) the adverse effect of the area granted to the operator on the remaining land of the owner or occupant and the nuisance, inconvenience and noise that might be caused by or arise from or in connection with the operations of the operator.

(d) the damage to the land in the area granted to the operator that might be caused by the operations of the operator, and

(e) such other factors as the Board considers proper under the circumstances.

83. Dome Petroleum Ltd. et. al. v. Swan Swanson Holdings Ltd, supra n. 72 at 512.

84. The Surface Rights Act, supra n. 18.

85. Waugh and Esquimalt Lumber Company $L$ td. v. Pedneault [1949] 1 W.W.R. 14 at 22 (B.C.C.A.); Hydro-Electric Power Commission of Ontario v. Grey (1924) 55 O.L.R. 339 at 341-2 (Ont. C.A.).

86 Thomson v. Halifax (1914) 16 D.L.R. 424 at 431 (N.S.S.C.en banc); Toronto Railway Com. pany v. Toronto (1906) 13 O.L.R. 532 at 538 (Ont. D.C.); Re Bronson and Ottawa (1882) 1 O.R. 415 at 428, (Q.B.D.); cf. Fort Garry R.M. v. Fort Garry School District (1958) 26 W.W.R. 443 at 451 (Man. Q.B.).

87. Re Bronson and Ottawa, supra, n. 86 at 428; Thomson v. Halifax, supra n. 86 at 431.

88. Toronto Railway Company v. City of Toronto, supra n. 86 at 538; Fort Garry R.M. v. Fort Garry School District, supra n. 86 at 447-451.

89. Dome Petroleum Ltd. v. Swan Swanson Holdings Ltd., supra n. 72 at 513.

90. Supra n. 18.

90a. Id. 


\section{A. Value of the Land}

In reviewing the value of the land as a basis for the amount of compensation payable pursuant to s.23(2) of The Surface Rights Act, comparison should be made with $s .40$ of The Expropriation Act.$^{91}$ Under s.40(2)(a) of The Expropriation Act, the compensation payable to the owner shall be based upon the market value of the land. By comparison, the value of the land under s.23(2)(a) of The Surface Rights Act is just one of the items that the Board may consider.

In Twin Oils $L t d$. v. Schmidt, ${ }^{92}$ Feir C.J.D.C. stated: ${ }^{93}$

... the Board is required to set, not a purchase price, nor even a rental, but compensation from the Appellant to the Respondent. In my view "compensation" in this setting means recompense for loss or damage.

Coming to the considerations which may apply in setting compensation, the first is set forth as "the value of the land". Again it must be stressed that this evaluation is not for the purpose of setting a purchase price, but rather to furnish a solid base upon which compensation for permanent damage, adverse effect on the remaining land, severance, etc., may be estimated. Since this is an arbitration proceeding the valuing process must be governed by the principles which have been evolved over the years.

In Dau v. Murphy Oil Company Ltd., ${ }^{\text {t }}$ the Supreme Court of Canada held that "the value of the land" meant value to the owner of the land, and confirmed that the principles applicable in expropriation matters should be applied in cases under The Right of Entry Arbitration Act, ${ }^{95}$ the predecessor of The Surface Rights Act.

In light of these and other judicial decisions, the Surface Rights Board (as it now is) adopted the approach, which it still maintains, of estimating as one of the heads of compensation, the damage to the surface and related damages. The Board on repeated occasions has held that it is not its function to determine a fair market value for the land, but rather to determine fair and just compensation for damage done or likely to be done to small portions of the land. This includes consideration of the factors set out in s.23(a) (value of the land) and (d) (damage to the land in area). However, it is clear from a review of the Surface Rights Board decisions and appeals taken therefrom to the Courts that the value of the land plays an essential role in determining what these damages should be.

Despite the distinction made by text-writers between "value to the owner" and "market value", ${ }^{96}$ decisions of the Surface Rights Board and the Courts have in fact referred to value to the owner and market value interchangeably. For example, in Great Plains Development Company of Canada Limited v. Lyka, ${ }^{97}$ Cormack D.C.J. used both "fair market value" and "value to the owner" in the same paragraph. In Redwater Water Disposal Co. $L t d$. v. Shopsky, ${ }^{98}$ Stevenson J. referred to market value. In Siebens Oil \& Gas Ltd. v. Livingston ${ }^{99}$ the Appellate Division of the

91. S.A. 1974, c. 27.

92. (1968) 74 W.W.R. 647 (Alta. Dist. Ct.).

93. Id, at 651 .

94. [1970] S.C.R. 861, affg. (1969) 70 W.W.R. 339.

95. R.S.A. 1955, c. 290.

96. See Eric C. Todd, The Law of Expropriation and Compensation in Canada (1976) $101 \mathrm{ff.,}$ $149 \mathrm{ff}$.

97. [1972] 6 W.W.R. 321 at 328 (Alta. Dist. Ct.).

98. (1979) 18 L.C.R. 294 (Alta. Q.B.).

99. (1978) 15 L.C.R. 32 at 36-37 (Alta. App. Div.). 
Supreme Court of Alberta referred to both the value to the owner and the market value of the land. Again, in Imperial Oil Ltd. v.Smulsk $i^{100}$ Bowen J. mentioned both "the full extent of the value of the land to the owner" and "the market value of the land".

From the above decisions it would appear that with respect to the interpretation of "the value of the land" referred to in s.23(2) (a) of The Surface Rights Act, the value of the land to the owner will be the same as the market value of the land, and will form one of the bases for compensation to the land owner. How this land value is to be calculated is a far more difficult question and one which will of course depend on the facts of each case as it comes before the Board or the Courts.

\section{Highest and Best Use}

In calculating the value of the land as a basis for compensation, the Board must first establish the highest and best use of the land. The value of the land is not necessarily based on the existing use to which the land is being put. In cases where land is not being used to its best advantage, the best use to which the land may be put is generally an element properly taken into account in determining the value of the land.

If the land is valued on the basis of some use other than its existing use, then there is authority to the effect that disturbance damages are not payable. This rule, as expressed in the leading case of Horn v. Sunderland Corp. ${ }^{101}$ was enshrined in The Expropriation Act, s.41. However, disturbance damages, as will be explained below, only play a minor part in the assessment of compensation for land acquired under The Surface Rights Act. As a result, problems of "double recovery" occur only infrequently in surface rights compensation hearings, and arguments based on the rule against double recovery in Horn v. Sunderland Corp. do not appear to have been made on surface rights hearings, at least in those cases reported.

The "highest and best use" is a term often found in expropriation statutes, ${ }^{102}$ and one which has been subjected to close judicial scrutiny. The best explanation of the term is probably that of Hewak Co. Ct. J. in Turner v. City of Winnipeg: ${ }^{103}$

It is that use of land which may reasonably be expected to produce the greatest net return to the land over a given period of time.

It has been emphasized that the expectations of future potential must be reasonable. Ritchie J.A. in Mitchell v. C.P.R. stated:104

The possibilities must be reasonably capable of realization and not too remote nor uncertain. $A$

chance should not be treated as a certainty nor a hypothetical purchaser as a purchaser in fact.

The scheme of future development must not only be a realistic possibility; it must also be one which the party whose land is expropriated had considered. Thus in Lake Louise Ski Lodge Ltd. v. The Queen, ${ }^{105}$ Gibson J. held that certain grandiose schemes of development prepared about ten years after the expropriation were not in the contemplation of any of the

100. (1980) 20 L.C.R. 20 at 23 (Alta. Q.B.).

101. [1941] 2 K.B. 26 (C.A.).

102. For example, s. 41(bXi) of The Expropriation Act, S.A. 1974, c. 27, as am..

103. (1972) 4 L.C.R. 319 at 323 (Man. Co. Ct.).

104. (1960) 44 M.P.R. 339 at 343 (N.B. App. Div.).

105. [1968] 2 Ex. C.R. 402 at 408. 
parties at the relevant date, the date of expropriation. Such schemes were not actual factors in the market at the date of expropriation and were therefore to be disregarded.

To what extent does a decision as to the highest and best use result in additional compensation? If a pipeline company expropriates an easement across farm land that is part of a future subdivision plan, is the farmer entitled to compensation at the per acre rate applicable to subdivided land?

In C.N.R. v. Grenn, Cattanach J. stated: ${ }^{106}$

It is well established that the value of expropriated property should be estimated on the basis of the most advantageous use that could be made of it, whether present or future, but it must be remembered that, while consideration must be given to the future advantages and potentialities of the property, it is only the present value as at the date of expropriation of such advantages and possibilities that falls to be determined.

Accordingly, the farmer, in the question posed above, cannot expect to be compensated at the per acre rate for land that is already subdivided, but only at the rate applicable to land that has similar subdivision potential. This is only logical. If the value of the land is to be established by reference inter alia to a willing buyer, no buyer is going to pay for the land the same sum that he hopes to receive from it, having spent time and money subdividing the property. He will only pay the present value of this future potential.

\section{Date at Which the Value of the Land is to be Assessed}

In Murphy Oil Co. Ltd. v. Dau ${ }^{107}$ McDermid J.A. cited the decisions of Woods Manufacturing Company v. The King ${ }^{108}$ and Diggon-Hibben Ltd. v. The King, ${ }^{109}$ to the effect that the time at which compensation is to be assessed for the value of the land is at the moment of expropriation, and quoted Lord Dunedin in Cedar Rapids Manufacturing and Power Co. v. Lacoste"10 wherein he stated: "The value to be paid for is the value to the owner as it existed at the date of the taking,..." "II

The "date of the taking" is of course the date of the right of entry order granted by the Surface Rights Board. Note also s.23(2.1) where the Board is given the power to assess additional compensation under the "homefor-a-home" provision including the increase in cost between the date on which the right of entry order was made and the time when the equivalent accommodation could reasonably be obtained.

\section{Comparable Sales Approach to Market Value}

Once the highest and best use of the land has been determined, the market value of that land remains to be calculated. Usually the most reliable method of establishing the market value of the land in surface rights expropriation cases has been found to be the "comparable sales approach". ${ }^{12}$ This approach was described in Metro Toronto v. Loblaw

106. [1965] 2 Ex. C.R. 537 at 548.

107. Supra n. 94, (1969) 70 W.W.R. 339 (Alta. App. Div.).

108. [1951] S.C.R. 504.

109. [1949] S.C.R. 712 at 715.

110. [1914] A.C. 569 at 576.

111. Cited supra n. 107 at 358.

112. In preference to the Income, Cost or Land Residual approaches: See Todd, supra n. 96 at $150 \mathrm{ff}$. 
Groceterias by Spence J. for the majority of the Supreme Court of Canada:113

The comparative method may be briefly described as the consideration of actual sales of like lands in a like area, and determination from such comparison of the going market value of the lands in question at the date of the expropriation.

How "like" those lands should be was discussed in Purdy v. Nova Scotia, 14 where McIntosh J. quoting from Challies, The Law of Expropriation, ${ }^{115}$ stated: ${ }^{116}$

... for evidence of other sales to be a fair criterion there should be reasonable similarity in conditions regarding the property, proximity of situation and if possible a likeness in use or in potentiality.

It is often not appropriate to look at small parcels of land (even where sales can be found) as a basis for comparison for surface rights expropriations. Notwithstanding that the expropriation is of a small number of acres, it is usually not comparable with small parcels used for commercial or residential purposes. This is particularly true when the land is farm land with no subdivision potential.

Very often the only evidence of other sales of small "like" parcels in the neighbourhood is provided by negotiated settlements between the operator and neighbouring land owners, or perhaps between other expropriating authorities and land owners. The Courts have adopted conflicting approaches to the evidentiary value of such settlements. On the one hand, they have been very wary of admitting settlements to show market value and have adopted the presumption that such sales are prima facie not free and voluntary. ${ }^{117}$ The reasons for the objection to admission of such data were discussed by Rand J. in Gagetown Lumber Co. v. The Queen: ${ }^{118}$

The objection to admission is that the power on one side to take and the necessity on the other ultimately to yield introduce factors that destroy freedom of action between the parties.

His Lordship continued: ${ }^{119}$

The primary question is of freedom in the negotiation as a fact, and it is for the tribunal, in the light of the circumstances, to say whether the price was influenced by extraneous elements, or whether the parties were concerned only to reach agreement on a figure deemed to be the fair value of the property.

If the circumstances surrounding the sale to the expropriating authority can be shown to support the contention that the figure agreed upon was a fair one and one freely agreed on, then the presumption that the sale was not voluntary will be rebutted. ${ }^{120}$ However, if no evidence other than records of sales can be produced, then the presumption still ap-

113. (1972) 21 D.L.R. (3d) 551 at 559; 1 L.C.R. 118 at 126. (S.C.C.).

114. (1973) 6 L.C.R. 70 (N.S.T.D.).

115. (2nd ed. 1963) 102-3.

116. Supra n. 114 at 74.

117. Whittaker v. Hydro-Electric Power Commission of Ontario (1972) 3 L.C.R. 74 at 82-3 (Ont. L.C.B.); Smegal v. City of Oshawa (1972) 2 L.C.R. 109 at 122 (Ont. L.C.B.); Budd v. Minister of Transportation (1979) 18 L.C.R. 37 at 41 (N.B. App. Div.) and cases there cited. This presumption is of course not applied if both parties agree to the admission of the relevant data.

118. [1957] S.C.R. 44 at 55.

119. Id. at 56.

120. Whittaker v. Hydro-Electric Power Commission of Ontario (Ont. L.C.B.), supra n. 117. 
plies. ${ }^{121}$ The burden of proving that the sales were freely negotiated is on the party who relies on them as comparable sales. ${ }^{122}$

Often there are circumstances where the operator is prepared to pay additional compensation because of time constraints. Where an operator pays to a landowner additional compensation for his land in order to be able to move his equipment onto the land at once, rather than pay for rig stand-by time, it would seem that objection could be made that the operator was not a "willing buyer". ${ }^{23}$

However, notwithstanding the authority referred to above, it is clear that the courts in Alberta are quite prepared to take into account evidence of settlements in the area, when assessing the value of the land in surface rights cases. ${ }^{124}$

In Siebens Oil \& Gas Ltd. v. Livingston, ${ }^{125}$ McDermid J.A. stated: ${ }^{126}$

... It is most important that when both parties have shown that they are satisfied by establishing a course of dealing in any area, this is very relevant evidence to be considered by the Board. The company may in an individual case pay more than it thinks is fair, for various reasons, and, as the Board states, little weight can be given to individual cases. But, in an area where there is a course of dealings between oil companies and surface owners whereby a standard rate of compensation has been paid and accepted, this evidence should at the very least be given great weight by the Board.

He continued by declaring that::27

... The Board is not bound to set compensation at the same amount as is offered by the oil company, for there may be reasons for the company's offering higher prices than they think they are bound to pay; it is a matter to be weighed by the Board. However, where there are such a number of deals established so that it may be said that a pattern has been established by negotiations between the land owners and oil companies in a district, then the Board should depart from such compensation only with the most cogent reasons. I think it should be accepted that no matter how expert outsiders are, the oil companies and land owners have the better judgment as to what compensation should be paid in their own interests.

Where negotiations are conducted on a large scale, such as agreements between exploration companies and large numbers of owners in one area, it may be very difficult for a subsequent resource company to refuse to negotiate with these farmers on the same basis. This problem will in fact only be exaggerated with each resource company making these large scale decisions. It is accordingly suggested that companies continue to deal with applications and negotiations as the circumstances warrant and preferably on an individual basis. From time to time urgent needs to settle a particular item will arise with respect to one or more parcels of land.

121. Smegal v. City of Oshawa (Ont. L.C.B.), supra n. 117.

122. Id, Re McLean and Municipality of Metro. Toronto (1975) 7 L.C.R. 308 (Ont. L.C.B.); In contrast, where sales in the open market to persons other than an expropriating au. thority are claimed by the landowner's appraiser to be comparable, these sales will be deemed to be comparable unless the expropriating authority challenges them. It is up to the expropriating authority to show that the sales are not comparable: Pasteris Bros. v. The Queen (1973) 5 L.C.R. 202 (F.C.T.D., Pratte J.).

123. On this point see Morden v. Hamilton Region Conservation Authority (1972) 3 L.C.R. 249 (Ont. L.C.B.), where a sale to an authority of a parcel for which the authority had been denied the right of expropriation was held not to be representative of market value since the authority was not a "willing buyer".

124. Great Plains Dev. Co. v. Lyka [1973] 5 W.W.R. 768 (Alta. App. Div.); Klaiber v. InterCity Gathering Systems Ltd. [1974] 4 W.W.R. 108(Alta. Dist. Ct.);Roen v. Pan Canadian Petroleum Ltd. (1977) 12 L.C.R. 143 (Alta. Dist. Ct.); Siebens Oil \& Gas Ltd v. Livingston [1978] 3 W.W.R. 484, 15 L.C.R. 32 (Alta. App. Div.).

125. Siebens Oil \& Gas Ltd. v. Livingstom, supra n. 124.

126. Id. at 489 (W.W.R.), 36 (L.C.R.).

127. Id., at 490 (W.W.R.), 37 (L.C.R.). 
These can be dealt with on an individual basis, and higher payments made if necessary to secure agreement. However, it is suggested that the reasons for this higher payment and the urgent settlement should be carefully and completely documented by the operator, so that if these payments are later held against the operator at a hearing before the Surface Rights Board, the payments can be explained in the light of the circumstances that surrounded them.

\section{Valuation of Small Parcels Where There Are No or Insufficient Comparable Sales}

The problem of insufficient comparable sales has been present in surface rights expropriation proceedings for a long time. It was recognized at an early stage that valuation of the strip taken at the value per acre of the whole parcel of land from which it was taken was not fair. ${ }^{128}$ It became the practice of the Public Utilities Board, under the chairmanship of G.M. Blackstock, Q.C., to add an extra fifty per cent to the per acre value of the whole parcel. ${ }^{129}$ Subsequently, the Alberta Appellate Division discussed the "Blackstock formula" in a number of cases, ${ }^{130}$ and disapproved the use of the formula where there was evidence of sales of small parcels. The Public Utilities Board adopted this approach, but was still of the opinion that, where there was no evidence of comparable sales, the use of the formula was appropriate. ${ }^{131}$

In Copithorne v. Shell Canada Ltd. $_{.}{ }^{132}$ however, McDermid J.A. rejected the use of an arbitrary formula altogether. Allen J.A. (with whom Cairns J.A. concurred) did not reject the formula in such a forthright manner, but repeated the principle that resort should not be had to the formula where there was evidence of other recent sales of comparable land. ${ }^{133}$

His Lordship reviewed the evidence of the appraisers and agreed with the Board that there was no evidence of sales of small parcels of comparable land (other than another transaction involving Copithorne and Shell). He noted that the Board had not accepted either appraiser's figure but had selected a value of its own, namely $\$ 140.00$ per acre. ${ }^{134}$

His Lordship continued: ${ }^{135}$

To this amount of $\$ 140.00$ per acre the Board added 50 per cent presumably as representing what it considered to be the difference between the acreage value of a quarter section and the acreage value of the smaller portion taken from it. Without expressing approval of any fixed formula of ascertaining the value of small acreage taken out of a larger parcel it seems to me that in all the circumstances the figure of $\$ 210.00$ per acre thus fixed as the value of the land is fair and reasonable.

128. Re Valley Pipe Line Co. Ltd. [1940] 3 W.W.R. 145(Alta. P.U.B.); Re Imperial Pipe Line Co. Ltd. and Pahal [1948] 2 W.W.R. 20 at 33 (Alta. P.U.B.).

129. Re Imperial Pipe Line Co. Ltd. and Pahal Re Valley Pipe Line Co. Ltd., supra n. 128.

130. Interprovincial Pipe Line v.Z.A.Y. Development Ltd. (1960) 34 W.W.R. (N.S.) 330 (Alta. App. Div.); Calgary Power Ltd. v.Danchuk(1962) 41 W.W.R. (N.S.) 124 (Alta. App. Div.); Copithorne v. Shell Canada Limited (1969) 70 W.W.R. 410 (Alta. App. Div.).

131. Calgary Power Ltd. v. Hutterian Brethren of Pincher Creek(1961) 35 W.W.R.(N.S.) 227 (Alta. P.U.B.).

132. Supra n. 130.

133. Id, at 415 .

134. Id, at 416 .

135. Id, at 416-7. 
It should be noted that McDermid J.A., despite his rejection of the use of a formula, otherwise concurred with Allen J.A., indicating that the value of the smaller parcel would vary with the facts of each case.

Some two weeks after the decision in Copithorne v. Shell Canada Limited, McDermid J.A. in Murphy Oil Company Ltd. v.Dau ${ }^{138}$ delivered reasons for judgment relating to compensation for a well-site and roadway ${ }^{137} \mathrm{McDermid}$ J.A. indicated that the highest and best use for the land in question was for agriculture. His Lordship continued: ${ }^{138}$

Based on sales in the district the appraiser placed a value on the 280 acres in which the expropriated lands were located at $\$ 175.00$ to $\$ 185.00$ per acre. I doubt as to whether the value per acre of the 280 acres serves any useful purpose in this case. As stated in Challies's, The Law of Ex. propriation, at p. 103:

Moreover, it must be remembered that the price paid for a small lot cannot be said to establish the market value for large areas. A valuation made on a lot by lot basis is subject to substantial reduction in order to arrive at the true value of the property on a basis of a sale en bloc.

The converse is likewise true, a valuation per acre of a large block of land would be subject to a substantial increase in price to arrive at the true value of the small lot.

Later in his reasons, in reviewing the yield from the expropriated lands, his Lordship distinguished between the lease of and revenue from the five acres taken and the entire landowner's acreage stating: "Again the fallacy is applying the same principle that is applied to a whole farm to a 5.28-acre piece."

In Caswell v. Alexandra Petroleums $L t d .{ }^{140}$ the Alberta Appellate Division considered an appeal respecting the compensation payable for a well-site and access roadway. Allen J.A. for the Court stated: ${ }^{\text {i1 }}$

As to value - it has not been the practice of the Courts in this province for many years to value a small piece of land taken out of a large area at the same price per acre that is fixed for a large area. For some years the Board of Public Utilities Commission applied what was termed "the Blackstock formula", which involved the application of a percentage increase over the acreage value of a large parcel when assessing the acreage value of the small piece taken from it. [Here his Lordship quoted from Copithorne v. Shell Canada $L t d^{142}$ and from Challies's Law of Expropriation. "']

In the absence of evidence of sales of comparable parcels of land in the vicinity one is compelled to, more or less, pick a figure out of the air in deciding what the acreage value of this small parcel must be in relation to the acreage value of the whole quarter section in which it is situated. As the Board has not been demonstrated to have been entirely wrong in its assessment of value and there was no evidence before the learned District Court judge to justify the disturbance of this award, I think it should have been allowed to stand.

His Lordship accordingly restored the award of the Board of Arbitration of $\$ 125.00$ per acre, even though it had been agreed by counsel before the Board that the land would have a value of only $\$ 50.00$ per acre if appraised on a quarter section basis. ${ }^{14}$

In Mayer v. Dome Petroleum Ltd., ${ }^{145}$ Foisy J. cited the comments of

136. (1969) 70 W.W.R. 339 (Alta. App. Div.); supra n. 107.

137. The reasons of McDermid J.A. were preferred by the Supreme Court of Canada on appeal: [1970] S.C.R. 861.

138. Supra n. 136 at 360.

139. The comments of McDermid J.A. were cited with approval in Roen v. Pan Canadian Petroleum Ltd. (1977) 12 L.C.R. 143 (Alta.D.C.). See also Redwater Water Disposal Co. Ltd. v. Shopsky (1978) 18 L.C.R. 294 at 300 (Alta. Q.B.).

140. [1972] 3 W.W.R. 706 (Alta. App. Div.).

141. Id, at 715.

142. Supra n. 130.

143. 2nd ed. p. 103-4, cited in Murphy Oil Co. Ltd. v. Dau: see text at n. 138.

144. Supra n. 140 at $711,714$.

145. (1979) 19 L.C.R. 117 (Alta. Q.B.). 
Allen J.A. in the Caswell case and also referred to the Lamb decision: ${ }^{146}$

In Lamb v. Canadian Reserve Oil \& Gas Ltd., Martland, J. decided that the District Court Judge in that case had properly applied the formula as there were no comparable sales where a small area was taken out of a large unit.

His Lordship proceeded to find that there were comparable sales of small units from larger parcels, so that the Blackstock formula ought not to be applied in this case.

In Swanson v. Dome Petroleum Ltd. ${ }^{147}$ Kane J.A. for the Alberta Appellate Division referred to the statement of the Public Utilities Board that the Board recognized that smaller parcels sell at a higher price than that which would prevail for a larger tract, and summed up the Court's findings on the question of land value as follows: ${ }^{148}$

I am unable to find that in fixing compensation for the taking at $\$ 5,000.00$ the Board has either proceeded on any incorrect principle or misapprehended some material evidence of fact and accordingly I would dismiss the appeal on that phase.

In 1976, Lamb v. Canadian Reserve Oil \& Gas $L t d .{ }^{149}$ came before the Supreme Court of Canada. In that case, the Board of Arbitration set up under The Surface Rights Acquisition and Compensation Act of Saskatchewan, had fixed the value of the land taken for a well-site and roadway at $\$ 130.00$ per acre and had added to this figure 50 per cent because the small parcel of 1.21 acres was being removed from the larger block of the landowner's farm. On appeal to the District Court, Bendas D.C.J. had confirmed this portion of the Board's order. In the Supreme Court of Canada, Martland J. stated:150

The District Court Judge had agreed with the application of what is known as "the Blackstock formula" in determining the value of the land. This formula was devised by Mr. G. H. Blackstock, for many years the chairman of the Alberta Board of Public Utility Commissioners, in respect of com. pensation awards for the expropriation of land for pipeline construction. Recognizing that it was unfair to the owner, on the expropriation of a small tract of land from a larger area, to pay him only the average value per acre of the whole area, he adopted the practice of increasing the average value per acre of the small tract by 50 per cent.

The Court of Appeal disagreed with the application of the formula in this case.

The District Court Judge made reference to the remarks of Allen J.A. in Copithorne v. Shell Canada L td. (1969) 70 W.W.R. 410 at 415:

With respect to the application of the so called Blackstock formula to the acreage in question it should be pointed out that the application of this formula has never been approved by this Court and in Interprovincial Pipeline Co. v. Z.A.Y. Developments Ltd. (1961) 34 W.W.R. 330 , and in Calgary Power Ltd. v. Danchuk (1963) 41 W.W.R. 124 (judgments delivered by Johnson J.A.) it is expressly stated that the Blackstock formula for computation of the value of expropriated land should not be resorted to where there is evidence of other recent sales of comparable land in the district.

He [Bendas D.C.J.] then went on to say [p. 315]:

However, where, as in the present case, there are no comparable sales and where a small area is taken out of a large unit an appraiser should apply the Blackstock formula in order to arrive at a fair value of the land.

In these circumstances, which involve his appraisal of the evidence before him, in my opinion his conclusion should not have been disturbed.

From this decision, it seemed that, although the Blackstock formula had never received "appellate sanction", it had now received the sanction of the ultimate authority. However, two recent decisions of the Alberta

146. Id, at 123.

147. (1973) 5 L.C.R. 174 (Alta. App. Div.).

148. Id, at 185.

149. [1976] 4 W.W.R. 79; 10 L.C.R. 1 (S.C.C.).

150. Id., at 91 (W.W.R.), 10 (L.C.R.). 
Court of Appeal have prevented or restricted the application of such a formula, at least until further review by the Supreme Court of Canada.

In The Queen v. Bonaventure Sales $L t d .{ }^{151}$ McGillivray C.J.A. delivering the oral judgment of the Court, held that the Land Compensation Board had erred in valuing a narrow strip of land expropriated pursuant to The Expropriation Act for a highway from the west boundary of the landowner's property as if it were a small 3.73 acre holding.

His Lordship continued: ${ }^{151 a}$

We are all of the opinion that under the provisions of the present Act and on the facts of this expropriation that treatment is not permissible. What was expropriated were two strips off the boundaries of the two parcels. They were not, of course, willing buyers or willing sellers of those strips. It is not reasonable to convert those strips into a saleable area of land for purposes of evalua. tion of that land per se. While the Board notes that the configuration is imposed by the Minister this does not mean that the strips should be treated as something they are not. We are all of the opinion that the only method of arriving at the fair market value was to take a fair market value of the whole of each parcel and then attribute the per acre value to the acreage taken. The fact that the land is classified for light industrial use, and development is taking place, are factors to be weighed in valuing the acreage to get a per acre value which can be applied to the land taken. It does not enable the Board to convert the strips into saleable small parcels and then put a value on to the parcel per se, as if it were something that could be sold as a small parcel. In the result we are of the opinion that the Board proceeded on a wrong principle in two respects: (a) in treating the land taken from two parcels as one; (b) in equating strips taken with saleable acreage and treating it as saleable acreage to be valued by itself.

No reference was made by the Court to the Blackstock formula nor any of the cases cited above, and indeed there had been no reference to such principles by the Land Compensation Board, nor in argument before the Court of Appeal.

The second decision is that of Cochin Pipelines Ltd. v. Rattray, ${ }^{152}$ an appeal from a decision of Stevenson J. sitting as an arbitrator under the provisions of the National Energy Board Act ${ }^{153}$ and the Railway Act. ${ }^{154}$ In that case the land taken was a 60 -foot easement for a high pressure pipeline. Stevenson J. stated that: ${ }^{155}$

It is clear to me from the authorities that apart altogether from the question of the residual interest value, recognition must be given to the fact that small parcels taken out of large parcels would, assuming a market, fetch a higher per unit price than the average per unit value of the whole parcel.

He held that there was no evidence of "a solid small parcel comparable" and adopted an additional allowance of 50 per cent, citing Copithorne v. Shell Canada Ltd. and Lamb v. Canadian Reserve Oil \& Gas Ltd., though noting the lack of express approval by the Court of Appeal.

On appeal, the Court was faced with an apparent conflict between The Queen v. Bonaventure Sales Ltd. on the one hand and Caswell, Copithorne and Lamb on the other. Haddad J.A. for the Court, ${ }^{156}$ held that Stevenson J. should have applied the principles in The Queen v. Bonaven-

151. Note the recent case of Kerr v. The Queen (1981) 22 L.C.R. 179 where the Court of Appeal, in a case where the land in question was valued part as highway commercial and part as recreational, held that "The Queen $v$. Bonaventure Sales $L t d$ has no application except where the acreage is homogeneous", and applied the higher (highway commercial) value to the acreage expropriated.

151a. Id.

152. [1981] 1 W.W.R. 732 (Alta. C.A.): revg. [1979] 6 W.W.R. 755. See also n. 159.

153. R.S.C. 1970 , c. N.6.

154. R.S.C. 1970 , c. R-2.

155. [1979] 6 W.W.R. 755 at 757 (Alta. Q.B.).

156. [1981] 1 W.W.R. 732 at 738 (Alta. C.A.). 
ture Sales $L t d$. by taking the market value of each quarter section and then applying the per acre value thereof to the land taken for the pipeline.

Haddad J.A. did not refer to the Caswell decision on this point but distinguished or explained the Copithorne and Lamb cases. The former was considered by his Lordship as a case dealing primarily with injurious affection, and hence not relevant to the case before the Court. The application of the Blackstock formula in the Lamb case was confined to the facts of that case.

With respect, neither decision can be dismissed in such fashion. In Copithorne, the two appraisers had arrived at two separate figures for the value of the whole quarter section from which the lands were taken. Shell's appraiser had arrived at a figure of $\$ 125.00$ per acre and the landowner's appraiser at $\$ 175.00$ per acre. Following a review of the evidence, Allen J.A. was of the opinion ${ }^{157}$ that the figure of $\$ 210.00$ per acre awarded by the Board was fair and reasonable in all the circumstances. Even if his Lordship did not express approval of any fixed formula, it is submitted there can be no doubt that he confirmed the judicial recognition of a higher price per acre for smaller parcels, in that case some $\$ 35.00$ per acre more than the highest per acre value suggested for the whole quarter section.

It is also difficult to see how the $L a m b$ case can be restricted as suggested by the Court of Appeal. The case involved the assessment of compensation for a typical well-site and access roadway containing 1.21 acres under Saskatchewan legislation similar to The Alberta Surface Rights Act. There was no evidence of comparable small parcels available. In Cochin Pipelines Ltd. v. Rattray, the Court quotes from Lamb: ${ }^{158}$

In these circumstances, which involved his [the District Court Judge's] appraisal of the evidence before him, in my opinion his conclusion should not have been disturbed.

The Court suggested that $L a m b$ be confined to its facts, apparently implying that the case turned solely on the facts and evidence there presented. With respect, the sentence quoted above cannot be plucked out of the judgment by itself. It must be read in its proper context (quoted in full above), and in particular should be read in conjunction with the immediately preceding passate: $:^{158 a}$

However, where, as in the present case, there are no comparable sales and where a small area is taken out of a large unit an appraiser should apply the Blackstock formula in order to arrive at a fair value of the land.

If the Supreme Court of Canada were of the opinion that the District Court judge's conclusion should not have been disturbed, it must have found that there was no error in principle nor any misapprehension of the evidence before the District Court judge. An error in principle would have warranted interference by the appeal courts. If, as appears from the Lamb decision, there was no error in principle by the District Court judge, this surely must have included the application of the Blackstock formula in cases where there are no comparable sales.

However, it should be noted that leave to appeal from the decision of the Court of Appeal in Cochin Pipelines Ltd. v. Rattray was refused by the Supreme Court of Canada. ${ }^{159}$

157. (1969) 70 W.W.R. 410 at 417 (Alta. App. Div.).

158. Supra n. 150.

158a. Id.

159. Leave to Appeal refused, 2 February 1981, Martland, Ritchie, Estey, JJ.. 
While these two recent decisions of the Court of Appeal appear to have clouded the principles expounded by the Courts over the last 40 years, it is suggested that in fact these two decisions mark the beginning of a realization by the Courts of the true origins of the Blackstock formula. Originally the formula proposed by $\mathrm{Mr}$. Blackstock, in such cases as In Re The Pipeline Act; In Re Valley Pipeline Company Limited ${ }^{160}$ and In Re The Pipeline Act; In Re Imperial Pipeline Co. Ltd. and Pahal ${ }^{161}$ included not only compensation for the land (on the basis of a fee simple taking), but also included damage caused through loss of fertility and damage caused through inconvenience in working the land and through weeds on the right-of-way, but did not include actual damage to crops on the right-ofway caused by the operator's use of it. What the 50 per cent addition included was normally something difficult if not impossible to calculate with any precision, and the application of the formula provided what in the Board's experience amounted to fair compensation. However, in subsequently applying the Blackstock formula the courts awarded this additional percentage increase for the value of the land taken, and in addition provided compensation for inconvenience, injurious affection and other damages. This is particularly true in $L a m b$ where the formula was applied to land taken for a well-site.

Where the land is purely agricultural land with no potential for subdivision, it may be that the application of the Blackstock formula to arrive at a figure inclusive of land value and adverse effect or injurious affection is appropriate. However, where definite evidence as to the adverse effect or injurious affection is available, or, of course, where there are "comparable sales of small parcels", such a formula has no application and the approach of the Court of Appeal in the Bonaventure case and the Cochin Pipelines case provides the only logical approach to the assessment of fair compensation.

\section{Residual/Reversionary Interest}

Where a pipeline is constructed beneath the surface of agricultural property, there is no doubt that, subject to some loss of productivity in the years following the installation, the farmer will in fact be able to farm over the pipeline as he was able to farm prior to the installation. In the case of a well-site and access roadway, the well itself may only have a life of a certain number of years, following which time the landowner will receive back the land duly restored pursuant to The Land Surface Conservation and Reclamation Act. ${ }^{162}$ In Murphy Oil Company Ltd. v. Dau, McDermid J.A. held: ${ }^{163}$

The Respondents are not entitled to the fee simple value of the lands being expropriated. The purpose in considering the value of the land is so that the interest which is being expropriated may be valued. The Respondents are losing their land for a term of years and not forever. It is the value of this term, indefinite as it is, that must be considered. The Respondents retain a reversionary interest. It was estimated that the well in question would produce for 25 years. This was an estimate only and there can be a great variation between the estimated and the actual life of the well.

In Re Interprovincial Pipeline Co. [1955] 0.W.N. 301, the Ontario Court of Appeal in valuing an easement said at p. 305:

160. Supra n. 128.

161. Supra n. 128.

162. S.A. 1973, c. 34. It may not be in exactly the same condition as before the well was drilled, but the landowner is initially compensated for this damage.

163. (1969) 70 W.W.R. 339 at 359 (Alta. App. Div.). 
... the proper approach to valuation of the easement taken was first to find the value to the owner of the fee simple at the date of expropriation, then find the residual value in the 60-foot strip after expropriation, and by deducting the latter from the former arrive at the value to the owner of the easement taken.

However his Lordship continued: ${ }^{184}$

This method of valuation is not appropriate in the instant case for although the value of the fee simple could be estimated, yet I see no satisfactory way of placing a value on the reversionary interest that the Respondents retain in the land being expropriated.

In Re Interprovincial Pipeline Co. ${ }^{165}$ the Ontario Court of Appeal found that any residual value of the 60 -foot strip taken was negligible, so that no deduction was in fact made for any residual interest. The same result occurred in the Murphy Oil case, so that no deduction was made for any residual value to the owner.

As a consequence (one suspects) of the results of these cases rather than the principles enunciated therein, various courts and boards in Alberta have taken the position that the practice in Alberta is to ignore the residual or reversionary interests in calculating the value of the land. The Institute of Law Research and Reform stated that "In Alberta our understanding is that the 'before and after' method is not in wide use" 168 and cited Re M.D. of Sturgeon v. Pelletier ${ }^{167}$ in support.

In Redwater Water Disposal Co. Ltd. v. Shopsky, ${ }^{168}$ Stevenson J. stated: ${ }^{169}$

My first concern is, then, the value of the land taken. This is not a fee simple taking. It is a taking for an indeterminate period of time. The value of the residuary interest is therefore difficult, if not impossible to assess. In Alberta it is common practice to ignore the residual value, a view taken by the Ontario Court of Appeal in Re Interprovincial Pipeline Co., which has been approved by our Courts, for example Re Murphy Oil Co. Ltd. v. Dau.

In Cochin Pipelines Ltd. v. Rattray, ${ }^{170}$ Stevenson J., sitting as an arbitrator, repeated his statements from Redwater Water Disposal Co. $L t d$. v. Shopsky, again referring to Murphy Oil Co. Ltd. v. Dau.

However, on appeal to the Court of Appeal of Alberta, ${ }^{1{ }^{1 i}}$ it was held that where there exists a residual or reversionary interest in favour of a landowner, the value of that interest, cannot be ignored in the course of fixing compensation. The tribunal assessing compensation must evaluate the evidence before it to determine the residual value in the land. The fact that this evaluation may be a difficult one does not mean that the tribunal should ignore that residual or reversionary value. ${ }^{172}$

The question that arises is how to calculate this residual or reversionary value. A submission was made before the Court of Appeal in the Cochin Pipelines case that the Ontario cases had valued the residual interest at 50 per cent of the market value of the expropriated land. In one of

164. Id.

165. [1955] O.W.N. 301.

166. Report No. 12, Expropriation (March 1973) 104.

167. (1968) 9 Alta. Public Utilities Board Decisions and Judgments 164.

168. (1979) 18 L.C.R. 294. (Alta. Q.B.).

169. Id. at 295.

170. [1979] 6 W.W.R. 755 (Alta. Q.B.). Supra n. 155.

171. [1981] 1 W.W.R. 732 (Alta. C.A.). Supra n. 152.

172. Citing Re Interprovincial Pipe Line Co. \& Union Gas Co. of Canada Ltd. v. O'Neill(1973) 5 L.C.R. 92 (Ont. C.A.). 
the Ontario cases cited by the Court of Appeal, ${ }^{173}$ the 50 per cent figure appears to have been based on previous proceedings relating to the same pipeline. However the Court of Appeal in the Cochin Pipelines case made it clear that this does not mean that in every case the residual value should be determined by arbitrarily discounting the market value by 50 per cent. The value of a residual interest in each case must be determined from the evidence.

From the Court of Appeal's decision in the Cochin Pipelines case and from the decision in Re Interprovincial Pipeline, ${ }^{174}$ there are a number of factors that have to be taken into consideration when assessing the residual value to the owner.

In the Cochin Pipelines case, the highest and best use of the land was for agricultural purposes, so that once the pipeline was buried the land could be used for agricultural purposes as it was before the pipeline was laid. However the land remained subject to the right of the pipeline company to go on or dig in it at any time. In fact the pipeline company had not placed the necessary evidence before the Court as to what the residual value should be. In Re Interprovincial Pipeline, ${ }^{175}$ there is a detailed consideration of the various factors which must be regarded in considering the residual value to the owner.

These factors include the following:

1. Future maintenance of the pipeline (although with modern technology and good engineering practice such maintenance will likely be kept to a minimum).

2. Inspections of the pipeline (much of these inspections are done by air rather than physical entry onto the right-of-way).

3. Construction of additional line or lines (if permitted).

4. If the land is zoned or becomes zoned for a use that is not compatible with the presence of the pipelines, the value to the owner of the land covered by the pipeline easement taken will become severely limited (and he may in fact never receive compensation for it).

5. The owner may require the consent of the pipeline company to build anything upon the easement. In particular he may be prevented from constructing roadways and other improvements over the pipeline. The owner may be prevented from fencing across the pipeline without the consent of the pipeline company, and even though the pipeline company may in all reasonable cases give the required consent, the owner cannot be sure of that and has no control over this consent.

6. The owner may still be liable to pay the property taxes with respect to the lands including the pipeline easements.

7. Upon subdivision of the land, services and indeed the configuration of the lots themselves may be seriously affected by the presence of a pipeline beneath the ground. The pipeline may be put into a utility lot, with the result that the land is lost for development purposes.

173. Interprovincial Pipe Line Limited v. Scott, unreported, (Ont. Co. Ct.. Honey J.); See also Kyrzakos v. Sudbury (1976) 9 L.C.R. 156 (Ont. L.C.B.).

174. Supra n. 165 at $306-308$.

175. Id. 
In cases where the land taken is all above ground, as in the case of a well-site and access roadway, the major consideration is the length of time for which the drilling company will require the land. There will be a substantial difference in the residual interests of the land if it is only required for two years as opposed to 25 years. ${ }^{176}$

From the Cochin Pipelines case it is clear that the onus is on the expropriating company to show what the residual value to the owner is in the particular case. ${ }^{\prime 7}$ A failure to do this will result in a finding that there is no residual interest. The Court will not attempt to make any arbitrary valuation of this residual interest.

It should be noted that s.55 of The Expropriation Act states as follows: ${ }^{178}$

On the expropriation of an easement or right-of-way, the Board, in making its award for the value of the interest taken, may ignore the residual value to the owner.

This section results from the recommendations of the Institute of Law Research and Reform ${ }^{179}$ and has the effect of enabling the tribunal assessing compensation under The Expropriation Act to avoid the requirements of the Cochin Pipelines decision, that the tribunal attempt to establish the residual value particularly in cases where the evidence is insufficient and such an assessment of the residual value would really be only a matter of speculation.

However, The Surface Rights Act does not contain a provision similar to s.55 of The Expropriation Act and there would appear to be no reason why the decision of the Court of Appeal in Cochin Pipelines should not apply to assessments of compensation under that Act, notwithstanding the difficulties this may cause the assessing tribunal.

\section{Expansion Within the Right-of-Way}

Where a company has already acquired or expropriated an easement for a pipeline or pipelines, it will normally have paid compensation for that easement on the basis of a full fee simple taking (now subject to the application of Cochin Pipelines Ltd. v. Rattray). What should the company have to pay for the subsequent expropriation of the residual or reversionary interest and the right to lay down more pipelines?

Until recently, it appeared to be a settled principle applied by the Surface Rights Board and its predecessors, that, where the compensation originally paid was based on the full value of the land, nothing more than a nominal award would be made for a subsequent pipeline in the same rightof-way.

In Home Oil Co. Ltd. v. Bilben, ${ }^{180}$ the Public Utilities board held that since the compensation for a pipeline right-of-way was awarded on the

176. However, it must be questioned whether the concept of "residual/reversionary value" is really relevant to what is in essence a lease situation. As discussed below, the landowner is compensated for "loss of use" and, as will be seen, where he is initially awarded the market value of the land, he is then paid annually for loss of use, and finally receives the land back, restored. In determining compensation in this fashion, the landowner is in effect being awarded double compensation.

177. [1981] 1 W.W.R. 732 at 744-5 (Alta. C.A.).

178. Supra n. 91.

179. Supra n. 166.

180. (1964), reported in 1 Lewis and Thompson, Oil \& Gas Law in Canada (1st ed. 1964) Dig. 220. 
basis of a complete taking of the fee (with no account taken of any residual value to the owner), the company was not required to pay any additional compensation (subject to payment for damage caused) since the landowner had already been fully compensated.

In Pembina Pipeline Ltd. v. Karbach, ${ }^{181}$ the Board of Arbitration considered a previous expropriation order by the Public Utilities Board which had given Pembina the "full and free liberty to lay,... take up, relay, maintain and repair ... pipelines for the purpose of conveying petroleum". The Board was of the opinion that compensation for the first taking was on the basis of full value of a fee simple taking. The Board compared the case where a strip of land is expropriated from Farmer " $A$ " in fee simple and the title vested in the expropriating authority, with the case where a company expropriates from Farmer " $B$ " only an easement for a pipeline. In both cases the expropriating authority pays full value for the strip taken, but in the latter case the company does not obtain title to the strip and does not have the freedom of ownership that the taker of the strip on Farmer "A" 's land obtains.

The Board continued: ${ }^{181 a}$

Is it reasonable that Farmer " $B$ " should receive full value for the second partial taking by the pipeline company for a second pipeline in the same strip of land? The Board does not think so. If Farmer " $B$ " were paid full value for the second taking he would end up with two purchase prices and still have his title and at least some use of the land, while Farmer " $A$ " would end up with only one purchase price, no title and no use of the land. This would be inequitable, and it is for this reason that the Board feels that since the first taking is less than the fee simple title but compensation for it is on the basis of a fee simple taking. then compensation for the second taking must be of a nominal nature.

The Board accordingly awarded $\$ 25.00$ for each quarter section crossed by the right-of-way.

In June of 1979, an appeal from the Surface Rights Board came before, Dea D.C.J. in Dome Petroleum Limited v. Hampson. ${ }^{182}$ Dome wished to take a third pipeline in the same right-of-way that contained two previous pipelines. On the taking of the initial pipeline right-of-way in 1969 an award of compensation was made as if the taking had been a fee simple expropriation. When the second line was laid in 1971, the Board followed its practice and only awarded nominal damages of $\$ 25.00$ per quarter section. ${ }^{183}$

On the third taking, Dea D.C.J. considered whether the landowner's reversionary interest in the right-of-way may or may not have been affected by this taking. ${ }^{184}$

If the pipeline located in the right-of-way by the third taking is no longer required by the Appellant at a time when either the first or second pipelines are still being used, then the Respondent's reversionary interest in the land is not affected at all by the current taking. If on the other hand pipelines one and two are no longer required by the Appellants but pipeline number three is still required, then it is seen that it is the interest acquired from the Respondents on the present taking that prevents the fee simple in the right-of-way from reverting to the Respondents. If that is the case, then the interest taken does affect the Respondents' residual interest in the right-of-way. The difficulty, if not the impossibility, of demonstrating with any degree of certainty the effect of the third party taking on Respondents reversionary interest considered with the fact that the Respondents were compensated on the first taking on the basis of a fee simple expropriation, suggests that the

181. Unreported, 1971, $71 / 8$ (Board of Arbitration).

181a. Id.

182. (1979) 10 Alta. L.R. (2d) 140.

183. Unreported, 14 November 1972, $72 / 17$ (Board of Arbitration).

184. Supra n. 182 at 144. 
analysis of the Surface Rights Board in decision 72-17 provides a legally approved disposition of the issue.

Accordingly his Honour was of the view that the value of the interest taken on the third expropriation was nominal only, and he fixed the value at $\$ 100.00$ per quarter section.

Twelve days after the decision of Dea D.C.J., Medhurst J. delivered his reasons for judgment in Alberta Gas Trunk Line Co. Ltd. v. Will Farms $L t d .{ }^{185}$ The facts of the case were very similar to those in Hampson. In 1965 , the expropriating authority obtained an order permitting it to construct a pipeline on a 100 -foot right-of-way. Although the taking of the right-of-way was considered to be less than the taking of the fee simple title, compensation was ordered and paid on the basis of a fee simple taking.

In 1977, the company expropriated, for a second pipeline, a further 25 feet (5.51 acres) adjacent to the land acquired under the order of 1965. At the same time it was permitted to re-enter on a portion of the right-of-way for the second line. The Board ordered compensation for the new 5.51 acres taken on the basis of the current market value of that acreage, but only awarded $\$ 100.00$ nominal compensation per lot for the re-entry over the original right-of-way.

On appeal, Medhurst J. varied the Board's order and held that the landowner was entitled to be compensated for all the land required by the pipeline company for the new pipeline, including the land in the original right-of-way, on the basis of the present value of the land.

Subsequent to the Will Farms decision, Cormack J., in Dome Petroleum Limited v. Schroter, ${ }^{186}$ deleted entirely the Board's award for the compensation based on land value, where the award was for the taking of land already subject to Dome's earlier easement.

The apparent conflict between the foregoing decisions came before the Court of Appeal, on appeal from the above decision of Medhurst J. by Nova, an Alberta Corporation (previously Alberta Gas Trunk Line Co. Ltd.).

The Court of Appeal rejected the reasoning of Medhurst J. and stated that there is no law which requires a pipeline operator to pay full fee simple value for the land it takes. However, the Court also rejected the position taken by the Surface Rights Board in the cases referred to above and held that over-compensation at the time of the first taking cannot later be adjusted by only awarding compensation for the re-entry on a nominal basis.

The Court held, following its decision in Cochin Pipelines Ltd. v. Rattray, ${ }^{188}$ that the first expropriation did not take the fee simple. It left to the landowner residual rights, including substantial occupational rights and the reversionary interest. The second taking diminished these residual rights by the interest taken. The Court held that the existing occupational rights were only marginally affected. The pipeline company was

185. (1979) 18 L.C.R. 103; 10 Alta. L.R. 263 (Alta. Q.B.).

186. Unreported, September 1979, Q.B. 242577 (Alta. Q.B.).

187. Nova an Alberta Corporation v. Will Farms Ltd., [1981] 5 W.W.R. 617 (Alta. C.A.) per Kerans J.A., McGillivray C.J.A. and Haddad J.A. concurring.

188. Supra n. 177. 
now entitled to enter to inspect, maintain and repair not just the first but also the second line. Since any damage caused by the entry itself would be separately compensable, in the Court's view the value of this further diminution of the landowner's interest was negligible and only warranted a token award.

The Court then questioned whether the second taking had any effect on the landowner's reversionary interest, and held that there would be no effect on the reversionary interest, unless the second line would survive the first. ${ }^{189}$ In the case before the Court of Appeal, no evidence had been provided by either side as to the extent of the diminution in value of the reversionary interest. The Court agreed with the statements of Stevenson J. in Cochin Pipelines Ltd. v. Rattray: ${ }^{190}$

While I am not saying that there is an onus on the taker, it seems to me that the taker is the only one that could give any realistic evidence as to the duration of the easement ... and, if it cannot show some value for it, I do not think the tribunal should make arbitrary assumptions against the owner.

The Court of Appeal continued that, if there had been no other evidence before it, it would have had to order a new trial or require the pipeline company to pay the full fee value. However, since it was agreed before the Court that the second line was merely a looping or twinning of the first line, the reasonable inference was made that the second line would only remain in the ground as long as the first. Accordingly the reversion would vest no sooner nor later than if there had been no second taking. It followed that there was no reduction in the value of the land in consequence of the second taking. As a result the award of Medhurst J. with respect to the compensation for re-entry was reduced to the $\$ 100.00$ for each parcel awarded by the Surface Rights Board.

Finally the case of Arychuk v. Calgary Power Ltd. ${ }^{191}$ should be noted as a case, not of expansion within the right-of-way, but rather of replacement of an entire power line within a pre-existing easement. In that case, easements had originally been obtained in 1929 by Calgary Power. When, in 1974, this power line became inadequate, the company sought and obtained the appropriate permit to upgrade the existing line by replacing the old line with a high energy capacity line using steel towers instead of the existing wooden poles. Once Calgary Power obtained its permit from the Energy Resources Conservation Board, it commenced the expropriation proceedings ${ }^{192}$ by registering notices of intention to expropriate against the required land. Subsequently certificates of approval were issued by the Surface Rights Board and registered at the appropriate Land Titles Office. The old easements were much narrower in scope than the new easements expropriated by Calgary Power, and it was conceded that the old easements did not within themselves contain terms which were broad enough to accommodate the new line and structures.

The Court of Appeal stated: ${ }^{193}$

I agree with the position put forward by Counsel for [Calgary Power] that his client by having an easement agreement is entitled to have it considered as diminishing the amount or value to be awarded in respect to the Respondent within the meaning of this section if the Appellant had in. tended to maintain its old interest. But such was not the case.

189. Quoting with approval Dome Petroleum Limited v. Hampson, supra n. 182 at 144.

190. Supra n. 170 at 757.

191. (1978) 17 L.C.R. 200 (Alta. C.A.).

192. Under The Expropriation Act, S.A. 1974, c. 27.

193. Supra n. 189 at 206. 
$\cdots$

At the very moment the expropriation took effect it was already known to both the Grantor and the Grantee that the old easement contract was to be used for at most only a few more months. If the expropriation did cut off the old easement so that the Grantee or Appellant was in improper operation under its former easement for those few months, it matters not in the view I take of it. What really happened here, in my opinion, was that the decision by the Appellant to go the expropriation route, to resort to expropriation which by the legislation gave it much wider powers than those already held on the old easements, constituted an abandonment of the old easements, or to use the language of the old agreements showed the Appellant no longer "desires and continues to maintain and operate its electrical pole transmission lines across the said land."

The Court held that the value of the old easement was so small that it should be ignored and referred the matter back to the Surface Rights Board for the awarding of compensation on the basis of a completely new expropriation.

\section{B. Loss of Use}

Where land is taken for a well-site, compensation for loss of use is awarded on an annual basis, since the landowner is being deprived of the normal use of the acreage taken for so long as the right of entry remains in effect. The Surface Rights Board takes the view that the compensation should approximate the value of the gross annual production reasonably to be expected from the area lost, as the major farming operating expenses, those relating to capital, labour, equipment and overhead are virtually unaffected by the loss of a small acreage. Some deduction must be made for direct production costs such as seed, fertilizer, etc. ${ }^{194}$

In Algas Mineral Enterprises Ltd. v. Van Oirschot, ${ }^{195} \mathrm{Kirby} \mathrm{J}$. awarded annual compensation for loss of use based on the "principle of substitution" referred to by the Surface Rights Board, to the effect that the worth of a commodity can be no greater than the value of an equally desirable substitute commodity, provided no costly delay is encountered in the substitution. His Lordship held that the farmer was harvesting alfalfa as haylage to augment the feed of his cattle with high protein content. In order to find an appropriate "substitute" for the crop that was no longer being grown on the well-site area, his Lordship accepted calculations designed to show an alternative method of feed which would attain a comparable protein nutritional value.

Where the land owner has been awarded compensation on the basis of the full value of the land, particularly where there is no deduction for the residual value, it is obvious that the award of an additional amount based on loss of use is a duplication of payments to the land owner. It is exactly as if the operator has bought the land and is in addition paying rent for this land that is now his own. Under the provisions of The Expropriation Act there is no possibility of the land owner receiving more than the market value of the land taken as compensation for the taking of that actual land. There are of course provisions permitting compensation for other matters such as disturbance damages and injurious affection, which are assessed quite separately.

This question of duplicate compensation came before the Supreme Court of Canada in Lamb v. Canadian Reserve Oil \& Gas $L t d .{ }^{198}$ In that

194. Accepted in Redwater Water Disposal Co. v. Shopsky (1979) 18 L.C.R. 294 at 297. (Alta. Q.B.).

195. (1981) 15 Alta. L.R. 204 (Alta. Q.B.).

196. [1976] 4 W.W.R. 79; 10 L.C.R. 1 (S.C.C.). Supra n. 149. 
case the Saskatchewan District Court judge, on appeal from the Board of Arbitration, was of the view that an owner in possession who has the use of the land is not entitled under s.24(1)(a) of The Surface Rights Acquisition and Compensation Act ${ }^{197}$ to receive the value of the land and also compensation for loss of use of the land, as that would be duplicate compensation. He was of the view that when the provision of the statute referred to "the value of the land and the loss of use of the land", the words "loss of use" were intended to apply only to cases where the owner did not enjoy the use of the land, for example, if the land has been leased, in which case the tenant would be compensated for loss of use while the owner would receive the value of the land.

The Saskatchewan Court of Appeal disagreed with Bendas D.C.J. and stated: ${ }^{198}$

The Board is thereby empowered to grant compensation for both value of the land and loss of use. This is both reasonable and practical and an illustration I merely add - if land value of say $\$ 130.00$ per acre was allowed and if the life of the well was 20 years, the annual or total return to the farmer on the basis of land value alone, could not be considered as reasonable compensation.

The Supreme Court of Canada, per Martland J., reviewed s.24(1)(a) of the Saskatchewan act, which was as follows:

24(1) For the purpose of determining the compensation to be paid for surface rights acquired by an operator, the Board shall consider the following matters:

(a) The value of the land and the loss of use of the land or an interest therein acquired by the operator. [emphasis added]

Martland J. continued: ${ }^{19}$

In my opinion, s.24(1) (a) requires the Board to consider both the value of the land and loss of use of the land. There is nothing which confines the consideration of "loss of use" to the case of an occupant. On the contrary, the addition of the words "or an interest therein" appears to be designed to cover that situation. It is the owner who suffers loss of use of the land. It is the tenant who suffers loss of use of an interest in the land. Logically, it is difficult to see why the operator should be required to make a larger total compensation where the land which he requires is leased than he would if the land is occupied by the owner himself.

The purpose of the Legislature in requiring the Board to consider both value and loss of use of the land may well be that it was dealing with situations in which oil operators were enabled compulsorily to obtain possession of relatively small areas of land, for the purpose of drilling, well sites, roadways, power lines and battery sites, out of much larger areas of farm lands. During the time that the operator requires possession of the lands which he needs for such operations the farmer is deprived of the use of that portion of his farm. As Maguire J.A., points out, compensation in respect of land value alone could be inadequate.

Whatever may have been the reason for the form which s.24(1)(a) took, it is clear that the Legislature, in providing for consideration of both value and loss of use, acted deliberately. The equivalent statute in Alberta. The Right of Entry Arbitration Act, was enacted much earlier, in the year 1947 (S.A. 1947, c.24). Section $12(2)(a)$ of that Act provided that:

12(2) The Board, in determining the amount of compensation may consider - (a) the value of the land;

(The emphasis is my own.)

That section, in other respects, covers the same ground as s.24 of the Saskatchewan Act.

His Lordship unfortunately did not explain why he had emphasized the word "may" nor did he go on to discuss what the result would have been had he been considering the Alberta statute.

However, this matter came before Bowen J. in Imperial Oil Ltd. v. $S m u l s k{ }^{200}$ where his Lordship had to review the same question in light of the Alberta statute.

197. Supra n. 19.

198. (1974) 7 L.C.R. 205 at 210 (Sask. C.A.).

199. Supra n. 194 at 90-91 (W.W.R.).

200. (1980) 20 L.C.R. 20 (Alta. Q.B.). 
His Lordship reviewed the reasoning of Martland J. in the Lamb case and stated as follows: ${ }^{201}$

Clearly his emphasis on the words in italics had some bearing on his decision although it is not clear what he would have decided had he been dealing with the Alberta Act which is permissive and not mandatory as is the Saskatchewan Act. Again, it is unclear whether or not the learned Judge's emphasis on the word "and" in the Saskatchewan Act is a determining factor in reaching his conclu. sions. The Alberta Act is not specifically conjunctive in this regard.

His Lordship held that compensation is payable in Alberta based on both the value of the land and the loss of use. However, he continued: ${ }^{202}$

It is my further view that in awarding compensation for both of these items that in reality double compensation is being allowed for the taking and, therefore, the value set on each head of compen. sation must be scrutinized with a great deal of particularity and care.

$\ldots$

... in view of the fact that damages are to be awarded both for the market value of the land and also the loss of use of it, the awards made under both these heads should be made in conjunction with each other and accommodated and adjusted accordingly.

....

Also as I have stated before, where both amounts are awarded great care must be taken in ascertaining amounts so as to be certain they are based on solid evidence.

In Van Oirschot v. Algas Mineral Enterprises $L t d,{ }_{0}{ }^{203}$ Kirby J. disagreed with the reasoning of Bowen J., as in his opinion the approach taken by Bowen J. did not accord with the concept of the "Blackstock formula" as explained by Martland J. in the Lamb case. However, Kirby $J$. did not explain further this failure to "accord with the concept of the 'Blackstock formula'" as it might affect an award for loss of use. With respect, the reference by Kirby J. to the Blackstock formula appears to confuse the compensation based on the value of the land with the compensation based on the loss of the land. It is submitted that the loss of use of the land as a separate basis for compensation has no relation whatsoever to the Blackstock formula and cannot be affected one way or the other by the application of the formula. This is particularly true in light of the recent decisions of the Alberta Court of Appeal restricting the use of any form of formula.

Comparison should be made between the provisions of The Surface Rights Act and The Expropriation Act. It does not appear logical to treat the expropriation of a small parcel of land taken by an oil company for a well-site in a different fashion from a strip of land taken by the Department of Transportation for highway expansion. Nevertheless the interpretation of the provisions of s.23(2) of The Surface Rights Act and s.40(2) of The Expropriation Act indicates a different method of assessing compensation depending on which Act governs. With respect, there does not appear to be any need for the difference in interpretation. Section 40(2) of The Expropriation Act states that compensation shall be based upon the four matters set out in sub-paragraphs (a) to (d) inclusive. Section 23(2) of The Surface Rights Act indicates that the Board may consider the items set out in sub-paragraphs (a) to (e) inclusive. To award compensation based not only on the full value of the land, but also on the loss of use of that land, will result in a completely different award depending solely

201. Id., at 22.

202. Id, at 22-3. See also Gaschnitz v. Westhill Resources Ltd. (1980) 13 Alta. L.R. 248 at 255 , where Forsyth J. refused a claim for loss of use where the land had been returned to the farmer on the basis that this would represent "double counting".

203. Supra, n. 195. 
upon the use for which the land is being expropriated. Since the use to which the taker will put the land has always been excluded from consideration when assessing compensation upon expropriation, this judicial interpretation appears to create an exception to that traditional exclusion.

\section{Adverse Effect}

Section 23(2)(c) of The Surface Rights Act provides for compensation based on:

... the adverse effect of the area granted to the operator on the remaining land of the owner or occupant and the nuisance, inconvenience and noise that might be caused or arise from or in connection with the operations of the operator.

It is interesting to note that the clause really contains two elements, the first being adverse effect or injurious affection to the remaining lands of the owner, and the second being the nuisance, inconvenience and noise arising from the operations. The two elements are not mutually exclusive and the Surface Rights Board may, and often does, include both elements in its awards.

In farming situations, the adverse effect results from the problems associated with farming around well-sites, access roads and battery sites. It relates to the reduced revenue the farmer will experience and the added costs he will incur due to the extra time required for turning, double application of fertilizer, seed, spray and the like, due to overlap, soil compaction, etc. Where the land has been subdivided or is ripe for subdivision, the adverse effect can be quite severe if the use of the land is for residential purposes. On the other hand, it may not exist at all if the use is for an industrial subdivision, as such use may well be compatible with the industrial use present on the well-site, battery site and roadway. ${ }^{204}$

The Board has considered the adverse effect which may result where a country residential subdivision is present, and has noted: $:^{205}$

... there will be certain indirect and incidental losses and costs which the respondent will be faced with annually as a result of being unable to sell those parcels [containing well-sites] and thereby having to hold title in his own name. There is little doubt that the municipal land tax will increase substantially on a per acre basis as compared with taxes applicable to its present agricultural use. The respondent will be deprived of the potential revenue from the sale of the parcels which, upon reinvestment, would earn an annual return on the investment.

Adverse effect has been found in cases where the landowner is simply living in the area of a sour gas well and includes, inter alia, having to watch for a danger signal from the well (a red indicator light). ${ }^{208}$

While a buried pipeline may not cause any adverse effect or injurious affection to a parcel of land which is being used strictly for agricultural purposes, the injurious affection which can result from such a pipeline may be quite severe where the land has subdivision potential. ${ }^{207}$

D. Damage to the Land

This item is customarily considered at the same time as consideration of "the value of the land".

204. Entex Petroleums Ltd. v. Kotyshym S.R.B. Decision C.5/81 at 8, although see Swanson v. Dome Petroleum Ltd. (1973) 5 L.C.R. 174. (Alta. App. Div.).

205. Turbo Resources Limited v. Thomas, S.R.B. Decision E.139/79, at 9.

206. Hanen v. Imperial Oil Ltd. (1980) 19 A.R. 208 at 211, 214 (Alta. Dist. Ct., Feehan J.).

207. Swanson v. Dome Petroleum $L t d$, supra n. 204.

208. Supra, pp. 20 ff.. 


\section{E. Other Factors}

\section{General Disturbance}

This expression is used to distinguish those nuisances, inconveniences, etc., which are peculiar to the first year, from those which recur annually throughout the life of the well. The latter are considered under "adverse effect". ${ }^{209}$ These items include negotiations with the operator's agents and attending the Surface Rights Board hearing. They also include, where appropriate, other items more generally classified as disturbance damages. ${ }^{210}$ These involve all the reasonable costs and expenses that are the natural and reasonable consequences of the expropriation. These would include costs in moving equipment, improvements, buildings, etc. which have to be removed from the proposed area taken.

\section{Mental Anguish}

The scope of "general disturbance" has recently been significantly expanded by the decision of Dorin v.Dyco Petroleum Corporation, ${ }^{211}$ where damages were awarded for mental anguish. Claims for such damages have in the past been refused by the courts in expropriation cases. ${ }^{212}$

In the Dorin case, after the well had been drilled, the owners had substantial trouble with escaping cattle due to inadequate fencing of the well-site. As a result of the continuing escapes by the cattle, the female landowner had to give up her teaching position, as the constant problems resulting from the well-site and the inadequate fencing subjected her to too much pressure. In addition the landowners were greatly concerned that the drilling of the well would affect their water supply. Although the drilling did not in fact affect the water supply, Moore J. was satisfied that the landowners endured several weeks of mental anguish concerning their water supply. During the course of drilling the landowners were subjected to noise twenty-four hours a day making sleep almost impossible. After the well was completed the landowners were unable to sleep due to the noxious gas fumes which escaped into the air from the well-site in close proximity to their house. Moore J. stated that he was satisfied the landowners had suffered a great deal of mental anguish as a result of the drilling of the well and the gas fumes, and accordingly awarded them $\$ 7,500.00$ compensation as damages for this mental anguish.

\section{Interest}

In 1976, The Surface Rights Act was amended ${ }^{213}$ to permit the Board to order that the operator pay interest at such rate as the Board considers just. Prior to this amendment the courts had implied a right to interest

209. Supra, pp. $60 \mathrm{ff}$.

210. See s. 48 of The Expropriation Act, S.A.1974, c. 27. These items were discussed briefly by the Court of Appeal in Robertson v. Calgary Power Ltd., (1981) 22 L.C.R. 210.

211. (1980) 30 A.R. 105 .

212. Zobel v. Municipality of Metropolitan Toronto (1969) 1 L.C.R. 139 at 152 (Ont. Co. Ct.) (such damage, even if proven, too remote); Motolanez v. City of Welland (1972) 2 L.C.R. 74 (Ont. L.C.B.) (claim not supported by evidence and too remote in any event); Topekian v. City of Brantford (1973) 5 L.C.R. 289 (Ont. L.C.B.), (even if claim compensable, insufficient evidence upon which to determine the monetary value of such a claim); Durkee v. Minister of Highways for Nova Scotia (1977) 12 L.C.R.53 at 65 (N.S.E.C.B.), (too remote).

213. S.A. 1976, c. 85 , s. 7. 
where appropriate on the basis of the landowner's entitlement to full compensation. ${ }^{214}$

Since then, it appears that the Board's award of interest has consistently been at a somewhat low rate. In Mayer v. Dome Petroleum Limited ${ }^{215}$ Foisy J. affirmed the compensation assessed by the Board but increased the rate of interest to $10^{3 / 4}$ per cent from 9 per cent as the Board rate was unrealistic. In a recent oral judgment of Feehan J., Seagull Resources Ltd. v. Hildebrand and Seutter, ${ }^{216}$ his Lordship dismissed appeals of the operator from the Surface Rights Board. However the rate of interest awarded to the landowners was increased to 16 per cent per annum.

\section{F. "Home for a Home"}

Following the introduction of s.45 of The Expropriation Act in 1974, The Surface Rights Act was amended in 1976 to include s.23(2.1):

(2.1) Where an owner or a purchaser of land is required to relocate his residence as a result of the making of a right of entry order, the Board shall, upon application therefor and after determining the amount of compensation under subsection (1), determine such additional amount as, in the opinion of the Board, is necessary in order to enable the owner or purchaser to relocate his residence in accommodation that is at least equivalent to the accommodation on the land in respect of which the right of entry order is made, and in fixing the additional amount of compensation the Board shall include the increase in cost between the date on which the entry order was made and the time when the new accommodation could reasonably be obtained.

It is rare that the operator requires land for a pipeline or well-site and access roadway that includes the residence of the affected landowner, although the residence may well be included where land is acquired for coal mining operations. However, it is worth noting the difference between s.23(2.1) of The Surface Rights Act and s.45 of The Expropriation Act. ${ }^{217}$ The latter will apply to expropriations, for example, involving the acquisition of land for power plants. ${ }^{218}$

Section 23(2.1) does not appear to be limited as is s.45 to the principal residence of the owner as the word "principal" is omitted from s.23(2.1). Whereas the additional amount awarded pursuant to $\mathbf{s . 4 5}$ is assessed after fixing the market value of the lands taken, pursuant to s.23(2.1) the Board does not assess this additional amount required, until it has determined all the compensation payable.

It is not proposed to review in detail in this article the "home-for-ahome" concepts. However, the concepts and principles have been dis-

214. See Todd, supra n. 96 at 362; Re Calgary Power Ltd. and Grobe (1963) 42 W.W.R. 413 (Alta. App. Div.); Northwestern Utilities Ltd. v. Timm (1964) 47 W.W.R. 415(Alta. App. Div.); Cremona v. Spence (1965) 50 D.L.R. (2d.) 131 (Alta. A.D.).

215. (1979) 19 L.C.R. 117 at 123 (Alta. Q.B.).

216. Unreported, April 1981, Q.B. 800315719.

217. Section 45 of The Expropriation Act, supra n. 35, reads as follows: 45.(1) Upon application therefor, the Board shall, after fixing the market value of lands used for the principal residence of the owners award such additional amount of compensation as, in the opinion of the Board, is necessary to enable the owner to relocate his residence in accommodation that is at least equivalent to the accommoda. tion expropriated, and in fixing the additional amount of compensation the Board shall include the increase in cost between the time of expropriation and the time when the new accommodation could reasonably be obtained.

(2) In this section "owner" means a registered owner or purchaser and does not include a tenant.

218. Supra, n. 35, s. 26(2)(d), as am. S.A. 1976, c. 85, s. $12(b)$. 
cussed in a number of cases to which reference should be made. ${ }^{219}$

G. Compensation for Rental Review

Sections 36 and 37 of The Surface Rights Act deal with the review of compensation payable under a surface rights order, and a surface lease respectively. ${ }^{220}$ Each section provides that the review applies only to orders or leases commencing on or after January 1,1972. Neither section provides guidelines that are to be considered by the Board in determining the review. Each section requires the Board to review the "rate of compensation" and this no doubt means that the Board is to award "full compensation" based on fair value to the owner and includes full compensation for the interest under review. ${ }^{221}$ It is suggested that the Board, when making its review of compensation under ss. 36 and 37, should look at s.23(2) as a guide and apply such of the elements of compensation referred to therein as are relevant on a review situation. It should be noted that neither s. 36 nor s. 37 expressly provides for interest to be paid on the amount of the annual compensation not paid in a timely fashion, nor does it specifically provide for the payment of costs. It is suggested that such elements are properly to be considered by the Board under the review procedure, and it appears clear that interest is properly awarded as part of compensation in such cases at common law. ${ }^{222}$ Section 33 of The Surface Rights Act deals with costs, and there is nothing in the Act stating or implying that costs are not to be allowed in review situations.

It is perhaps tempting to argue that s.37, dealing with review of rentals under surface leases, should be strictly construed as this section interferes with the contractual rights of the parties. However, on reflec-

219. Surface Rights Board:

Tinney v. Calgary Power Ltd, S.R.B. Decision 80-1E; Ewashko v. Calgary Power Ltd., S.R.B. Decision 81-1E.

Land Compensation Board:

Bartkiewicz v. Edmonton (1977) 13 L.C.R. 79.

Abasand Holdings Ltd. v. Minister of Transportation (1978) 17 L.C.R. 76.

Grice v. Edmonton (1979) L.C.B. Order $\# 67$.

Schacht v. Edmonton (1979) 18 L.C.R. 214.

McNaughton v. Cardston Municipal Hospital District (1979) 19 L.C.R. 163.

Warnock v. Calgary (1980) L.C.B. Order $\# 82$.

Tribunals in Other Jurisdictions:

Madsen v. Toronto (1970) 1 L.C.R. 27 (Ont. C.A.).

Loukras v. The Queen (1974) 7 L.C.R. 240 (F.C.T.D.).

Forsyth v. The Queen (1975) 9 L.C.R. 12 (F.C.T.D.).

MacKenzie v. The Queen (1975) 9 L.C.R. 24 (F.C.T.D.).

Edwards v. The Queen (1975) 9 L.C.R. 46 (F.C.T.D.).

Doll v. Essex County R.C. School Board (1975) 9 L.C.R. 221 (Ont. L.C.B.).

Cotton v. The Queen (1976) 10 L.C.R. 350 (F.C.A.).

Kaschuk v. Credit Valley Conservation A uthority (1976) 11 L.C.R. 250 (Ont. L.C.B.). Durkee v. Minister of Highways for the Province of Nova Scotia (1977) 12 L.C.R. 53 (N.S., Expropriations Compensation Board).

Murray v. The Queen (1977) 12 L.C.R. 118 (F.C.T.D.).

Re Callow and City of Winnipeg (1977) 13 L.C.R. 1 (Man. C.A.).

Daues v. The Queen (1977) 13 L.C.R. 10 (F.C.T.D.).

Woolger v. The Queen (1977) 13 L.C.R. 243 (F.C.A.).

Farmer v. The Grand River Conservation A uthority (1978) 15 L.C.R. 289 (Ont. H.C.).

Veitch v. Minister of Housing (1978) 16 L.C.R. 147 (Ont. L.C.B.).

Horsman v. Moncton (1978) 16 L.C.R. 271 (N.B., Property Compensation Board).

The Queen v. Gerencer (1979) 18 L.C.R. 1 (S.C.C.).

220. Supra text to n. 69 ff..

221. Todd, Supra n. 96 at 35.

222. Supra n. 212. 
tion, it must be remembered that the whole tenor of The Surface Rights Act is a departure from the common law right of the mineral owner to go on and use the surface to extract its mineral without compensation to the surface owner. ${ }^{223}$

H. Appeals

1. Scope of Appeal

Section 24(2) of The Surface Rights Act provides:

(2) The operator or any respondent named in a compensation order may appeal a compensation order to the Court of Queen's Bench as to the amount of compensation payable or the person to whom the compensation is payable or both.

Section 24(1) provides: ·

(1) Except as otherwise provided for in this section, an order of the Board made in writing is final and there is no appeal therefrom.

It is clear from the above sub-sections that only a compensation order (as defined in s.24(3)) may be appealed. The original right of entry order may not be appealed. ${ }^{224}$

It should also be noted that it is the order of the Board that is appealed, and not the decision or reasons for judgment. In McKee v. Sulpetro of Canada $L t d .{ }^{225}$ Holmes D.C.J. held that, although the landowner had appealed from the Surface Rights Board's decision, and although the order was a separate document, nevertheless the Court had the inherent power to amend the Notice of Appeal and to substitute the word "order" in the Notice of Appeal where the words "Board decision" appeared. Holmes D.C.J. noted that the operator was not prejudiced nor had it been deprived of a right to a fair hearing by reason of the amendment.

Section 24(1), despite its express wording, does not affect the right of appeal from a decision of the Surface Rights Board under the provisions of The Expropriation Act, s. 35. ${ }^{226}$

\section{Time}

Section 24(4) provides that the party appealing must file a Notice of Appeal with the Court of Queen's Bench in the Judicial District in which the land is situated within 30 days of the date of the Board order. The Board and the other parties to the compensation order must be served personally or by registered mail within ten days after the filing of the Notice of Appeal. As with all statutory time periods (as opposed to those time periods provided by the Rules of Court) the Court has no power to enlarge this statutory time period, no matter what injustice may occur. ${ }^{227}$

\section{The "New Hearing"}

Section 24(7) provides:

(7) An appeal to the Court of Queen's Bench shall be in the form of a new hearing.

223. See Siebens Oil \& Gas Ltd. v. Livingston (1978) 15 L.C.R. 32 at 36 (Alta. App. Div.).

224. B.P. Exploration Canada Ltd. v. Hagerman (1978) 12 A.R. 165 (Alta. Dist. Ct.) . However, the possibility of claiming one of the prerogative writs still exists, particularly in light of the restricted appeal provisions in the Act.

225. (1978) 20 A.R. 102 (Alta. Dist. Ct.).

226. E.g. Valentini v. Amerada Mineral Corporation of Canada Ltd. (1977) 1 Alta. L.R. (2d) 66 (Alta. App. Div.); Re Calgary Power Ltd. and Henkel (1976) 10 L.C.R. 136 (Alta. A.D.); Arychuk v. Calgary Power Ltd. (1978) 17 L.C.R. (Alta. App. Div.).

227. B.P. Exploration Canada $L t$. v. Hagerman, supra n. 224; See also Flower v. Bright (1862) 70 E.R. 1194 at 1195; B.C. Permanent Loan Co. v. C.N.R. [1922] 2 W.W.R. 579 (Sask. C.A.); Re Fair and Toronto (1930) 65 O.L.R. 176. 
The scope of this new hearing was circumscribed by the Supreme Court of Canada in Lamb v. Canadian Reserve Oil \& Gas L td. :228

In my view the appeal provision in question here is not, in its context, analogous to the provisions as to trial de novo contained in the Criminal Code dealing with appeals from summary convictions. In an appeal from a summary conviction the appellant is seeking a complete reversal of the judgment at trial, and the appeal takes the form of a trial de novo before a judge who stands higher in the judicial hierarchy. The decision involves the application of law to the facts adduced in evidence and the decision is made on the appeal upon the evidence presented at the trial de novo. An appeal under the $A$ ct is concerned with the assessment of compensation and involves the determination, inter alia, of land values, damage to land, the effect upon land resulting from the right of entry and allowance for nuisance. The appeal is to a district court judge, at the judicial centre nearest to the land in question, who is not a specialist in these matters. He hears evidence, and, it may be, fresh evidence. He can assess the credibility of the witnesses, but in determining land values, the adverse effect on other land resulting from right of entry and compensation for nuisance, he should have some regard for the opinion of the Board. By this means a measure of equitable compensation can be achieved which will be uniform throughout the province, rather than varying decisions by different district court judges in various areas of the province.

In the Lamb case, the Supreme Court of Canada approved and confirmed the judgment of Allen J.A. in Caswell v. Alexandra Petroleums Ltd.:229

... although I have pointed out that the hearing is in the nature of a trial de novo, it is nevertheless an appeal from the findings of the tribunal making the award. Tribunals such as the Right of Entry Arbitration Board may be presumed generally to be selected because of knowledge or experience in the field in which they are to operate. They are dealing with these types of cases very frequently and they must be deemed to gain knowledge of their particular field through that experience. When they make detailed findings of fact, as they did in this case, after viewing the area and hearing representations from both sides, and render written reasons as extensive as they did in this case, I think that their findings should not be lightly disturbed. In other words I think it would require cogent evidence to establish where they were wrong and why their awards should be varied or revised upward or downward. The very informality of their proceedings may suit the type of case with which they are dealing better than formal court procedure.

These boards were set up to meet a demand that compensation be fixed on a fair and adequate basis where lands or rights are expropriated for private operations, and considerable weight should be attached to their findings, except where they are clearly demonstrated to be wrong.

Since the Caswell and Lamb decisions, the Courts have regularly reiterated these principles, so that in cases where the Surface Rights Board's decision is varied, it will inevitably be on the basis that "cogent evidence" has been produced before the Court on appeal to show that the Board was wrong. As expected, the question of what amounts to "cogent evidence" is one that must be determined on the facts of each case on appeal.

\section{Cross-Appeal}

In Dome Petroleum Limited v. Hampson ${ }^{230}$ Dea D.C.J. dealt with the argument that he should not consider the Respondent's claim for injurious affection because the Respondents did not cross-appeal. Mr. Justice Dea distinguished between the appeal by way of rehearing from the Surface Rights Board and the appeal to what was then the Appellate Division from the decision of a District Court judge. On the latter type of appeal, the rules and practice applicable to appeals to the Appellate Division apply and the failure of the party to cross-appeal would result in the refusal by the Appellate Division to consider the matter. ${ }^{231}$

228. (1976) 10 L.C.R. 1 at 7 (S.C.C.).

229. [1972] 3 W.W.R. 706 at 728 (Alta. App. Div.).

230. (1979) 10 Alta. L.R. (2d) 140 (Alta. Dist. Ct.).

231. Siebens Oil \& Gas Ltd. v. Livingston (1978) 15 L.C.R. 32 at 38 (Alta. App. Div.). 
However, on an appeal by way of a rehearing by the Court of Queen's Bench, a cross-appeal on the questions raised on the appeal is unnecessary. Once an issue is raised on appeal by way of rehearing, the whole amount of the compensation payable is at issue and not just those portions of the compensation order which the Appellant considers to be in error. ${ }^{232}$ However, if the only matter appealed is the amount of compensation, the Court of Queen's Bench on appeal cannot hear evidence or dispose of any dispute respecting the party to whom the compensation is payable, unless there has been a cross-appeal on that issue. This is a totally separate matter from the question of the amount of compensation and must be the subject of a cross-appeal if it is to be considered by the Court.

\section{Costs}

\section{Section 24(10) provides:}

(10) The costs of an appeal under this section

(a) if the appeal is by the operator, shall be payable by him on a solicitor and client basis regardless of the result of the appeal, unless the court finds special circumstances to justify it to award costs on any other basis, or

(b) if the appeal is by the owner or occupant,

(i) where the appeal is successful, shall be payable by the operator on a solicitor and client basis, and

(ii) where the appeal is unsuccessful, on a party and party basis to such party, if any, as the court in its discretion may direct.

From this sub-section it is clear that the prospect of an appeal is a daunting one from the point of view of the operator. It will be a rare occasion where the court finds "special circumstances" existing to justify a different basis for costs where the operator appeals or where the appeal by the landowner is successful. It should however be noted that the mere fact that the court increases the award of the Board does not necessarily mean that the appeal is "successful". In cases where the landowner has only obtained a small increase in the Board's award, notwithstanding claims for a large increase, the Court may feel that the award is not so "successful" to warrant solicitor-and-client costs and will award costs on a lower (party-and-party) basis.

For some years concern was expressed that the awards of costs, particularly those of the Surface Rights Board, did not reflect the intent of the Act that the owner receive full reimbursement of his legal costs.

\section{In Cochin Pipelines Ltd. v. Rattray, Haddad J.A. stated: ${ }^{233}$}

In awarding costs I would adopt the rule expressed by the learned arbitrator in connection with forced takings: that is to say, that the landowner ought not to be out of pocket. On that basis he ought to be reimbursed by the Appellant on a solicitor and client basis.

Since this decision the awards of costs appear to follow this principle and more closely reflect present day legal costs. ${ }^{234}$

232. See also Libra Holdings $L$ td. v. Westhill Resources Ltd. (1978) 8 Alta. L.R. 110, where Legg D.C.J. reduced the award of compensation to the landowner, notwithstanding the fact that the operator had not filed a Notice of Cross Appeal.

233. [1981] 1 W.W.R. 732 at 745 (Alta. C.A.).

234. The principles enunciated in the Cochin Pipelines case were again applied by the Court of Appeal in Robertson v. Calgary Power Ltd, (1981) 22 L.C.R. 210. 


\section{Court of Appeal}

Section 24(9) provides for an appeal from the Queen's Bench to the Court of Appeal by leave of a judge of the Court of Appeal. On such an appeal, the rules and practice applicable to the Court of Appeal apply, except as to costs, where s.24(10) continues to apply. The application of the Rules of Court to appeals to the Court of Appeal will of course include, where appropriate, extension by the Court of Appeal of time within which to file the Notice of Appeal, in contrast to the statutory time limit for appeals from the Surface Rights Board to the Court of Queen's Bench.

\section{COMPENSATION LEGISLATION IN BRITISH COLUMBIA} AND SASKATCHEWAN

\section{A. British Columbia}

Compensation for compulsory taking of pipelines in British Columbia is to be ascertained as the arbitrators deem best. ${ }^{235}$ This remains the case although arguments for statutory changes setting out the basis on which the compensation is to be awarded have long been made. ${ }^{236}$ The costs of the arbitration are to be borne by the company only if the arbitrators' award exceeds the sum offered by the company, otherwise they shall be borne by the opposite party and deducted from the compensation. ${ }^{237}$

The Board of Arbitration determines compensation for well-sites, access roads, flow lines and power lines acquired by mineral interest holders under the Petroleum and Natural Gas Act. ${ }^{238}$ Section 25 sets out the matters that the Board may consider in determining the amount of compensation, namely:
(a) the compulsory aspect of the entry, occupation or use;
(b) the value of the land and the owner's loss of a right or profit with respect to the land;
(c) temporary and permanent damage from the entry, occupation or use;
(d) compensation for severance;
(e) compensation for nuisance and disturbance from the entry, occupation or use;
(f) money previously paid to an owner for entry, occupation or use;
(g) other factors the Board deems applicable; and
(h) other factors or criteria fixed by regulation.

In addition, the Board shall consider any change in the value of money and of land since the date the surface lease, order or authority was originally granted or last granted. ${ }^{239}$ The Board may award costs incidental to any proceedings before the Board and the Board may fix the amount of costs and determine by whom they shall be paid. ${ }^{240}$ The only appeal from an order of the Board is on a question of law..$^{241}$

\section{B. Saskatchewan}

In determining the compensation to be paid for pipelines, s. 35(3) of The Expropriation Procedure Act ${ }^{242}$ merely lists some of the matters with

235. Railway Act, supra n. 43, s. 54(1).

236. A.R. Lucas, Compensation for Oil and Gas Surface Rights in British Columbia, Paper Presented to the Canadian Bar Association, (September 1970) 17 at 22. See also The Law Reform Commission of British Columbia, Report on Expropriation (1971).

237. Railway Act, supra n. 43, s. 56(1).

238. The Petroleum and Natural Gas Act, supra n. 19.

239. Id., s. 21(2).

240. Id., s. 27.

241. Id., s. 24(2).

242. Supra n. 65. 
respect to which the parties must state the material facts in their statement of claim or statement of particulars if they intend to rely on these facts at trial. These matters include:

(a) the best use that can be made of the expropriated land;

(b) any zoning laws applicable to the expropriated lands;

(c) designation of land that may be claimed to be comparable to the expropriated land, the sale of which could form a basis for the opinion of the value of the expropriated land;

(d) damage caused by the severance of the expropriated lands from other land:

(g) the fair market value of the parcel of land from which expropriation was made, both before and after expropriation;

(h) the sum or each of the several sums claimed by the owners as damages.

From these provisions it appears that the judge is to determine compensation on basis of "market value", which is not defined in the Act, and is to take account of the best use of the land given the applicable zoning laws. Residual value is to be taken into account.

The principles to be applied for determining compensation under flow lines and service lines on the one hand, and well-sites, battery sites and roadways on the other, are not the same.

Section 29(1) of The Surface Rights Acquisition and Compensation $\mathrm{Act}^{243}$ sets out the matters to be considered when compensation for flow lines, well-sites, battery sites and roadways is to be determined. These are:

(a) the value of the land and the loss of use of the land or an interest therein acquired by the operator;

(b) the area of land that is or may be permanently or temporarily damaged by the operations of the operator;

(c) payment or allowance for severance;

(d) the adverse effect of the right of entry on the remaining land by reason of severance;

(e) payment or allowance for nuisance, inconvenience, disturbance or noise, to the owner and occupant, if any, or to the remaining land. that might be caused by, arise from or likely to arise from or in connection with the operations of the operator;

(f) where applicable in the opinion of the board, interest at a rate to be fixed by the board;

(g) any other matter peculiar to each case, including the cumulative effect, if any, of the surface rights previously acquired by the operator or by any other operators under a lease, agreement or right of entry existing at the time of acquisition of the surface rights with respect to the land;

(h) such other factors as the board deems proper, relevant and applicable.

The Board may allow the owner or occupant reasonable costs and expenses incurred by them relating to the hearing.

With respect to flow lines or service lines, s. 47(1) of the Act sets out the matters to be considered when determining compensation. The section provides that the compensation to be paid for the purposes of making the survey or whatever other examinations or arrangements are necessary to fix the site of the right of way and the compensation for the actual right of entry and occupation of the land are to be considered separately. With respect to the latter, the following matters are to be considered:

(a) the value of the land and the loss of use of the land or an interest therein acquired by the operator:

(b) the area of land that is or may be permanently or temporarily damaged by the operation of the operator;

(c) payment or allowance for severance;

(d) the adverse effect on the remaining land by reason of severance;

243. Surface Rights Acquisition and Compensation Act, supra n. 19. 
(e) where an easement or other interest only in land is acquired, the value of the land included in the right of way or other interest determined according to subclause (a) less the value of any rights of use or possession remaining to the owner with respect to such land;

(f) payment or allowance for nuisance, inconvenience, disturbance or noise to the owner that might be caused by, arise from or in connection with the operations of the operator and damage, if any, to any adjoining land of the owner, and any other damage to or loss of crop, pasture, fences and livestock;

(g) damage or loss to the occupant, if any, for any of the factors mentioned in subclauses (a) to (f) insofar as they relate thereto.

The Board may also award additional compensation for a further three year period after the year in which the right of way is taken, as annual rental which shall not exceed 50 per cent of the amount granted in the first year in any one of the succeeding three years. ${ }^{24}$ Costs may again be awarded to the owner or occupant.

There is an appeal from a compensation order to the Court of Appeal on a question of law or jurisdiction of the Board, but leave to appeal must be granted by the Court. ${ }^{245}$

\section{A. Bill $C-60$}

\section{TRENDS}

As of June 9, 1981, Bill C-60, An Act to amend The National Energy Board Act, has been passed by the House of Commons and the Senate, but has yet to be proclaimed. Upon proclamation, the federal legislation relating to expropriations for inter-provincial pipelines will fall in line with the Alberta and Saskatchewan legislation dealing with intraprovincial pipelines.

The amendments contemplate notice to the landowner of the proposed pipeline and, where an objection is received from an affected person, a hearing will be held to determine the specific route of the pipeline, and the most appropriate methods and timing for acquisition of the lands and for construction of the pipeline. ${ }^{246}$ On such a hearing the Board has jurisdiction to refuse to approve the plan, profile and book of reference submitted by the pipeline company. ${ }^{247}$ Costs of such a hearing incurred by the landowners will likely be borne by the pipeline company. ${ }^{248}$

Acquisition of lands for an inter-provincial pipeline will now be governed by the National Energy Board Act. The land may be acquired by negotiation, but the agreement must include annual or periodic payments if the owner requires it. ${ }^{249}$ Similarly, if the land is acquired by way of expropriation, compensation is to include annual payments if the landowner requires it. ${ }^{250}$

Upon the application of the pipeline company the Board may grant right of entry prior to compensation being paid. ${ }^{251}$ In such circumstances the owner is entitled to an advance on the amount of compensation which he will eventually be entitled to receive. ${ }^{252}$

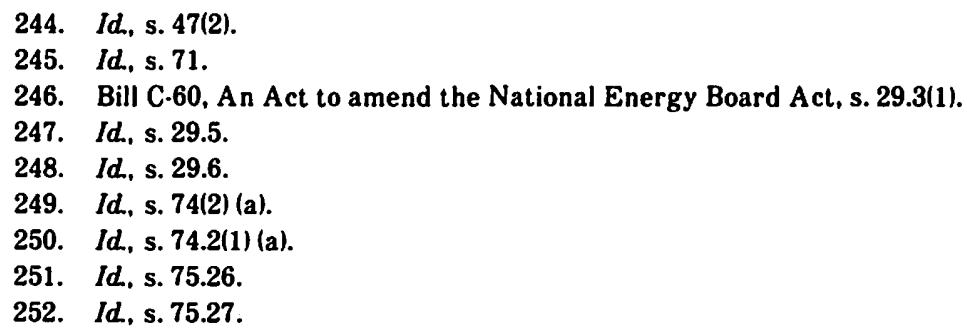


If the lands are to be acquired by expropriation, the company must provide a description of the lands that it requires, detail the amount of compensation offered, set out the value of the lands with respect to which compensation is offered, describe the detailed route of the pipeline and describe the procedure available for negotiation and arbitration under the Act. ${ }^{253}$

An agreement entered into before such notice is given is void. ${ }^{254}$ Should the company decide to abandon its plan to construct a pipeline, any damages suffered and reasonable costs incurred by the landowner are to be paid by the company. ${ }^{255}$

In the absence of an agreemeic, either side may serve notice that a negotiator is to be appointed to meet with the parties in an informal manner in an attempt to negotiate a settlement. ${ }^{256}$ If such negotiation fails, then arbitration proceedings will settle the amount of compensation. The Minister appoints an Arbitration Committee to consider the matter. It is to consist of not less than three members. The Arbitration Committee has the same powers with respect to the examination of witnesses, production and inspection of documents and the enforcement of its orders as are vested in a superior court of record. ${ }^{257}$

In determining compensation the Arbitration Committee is to consider the following factors where applicable: ${ }^{258}$

(a) the market value of the lands taken by the company:

(b) the loss of use to the owner of the lands taken by the company;

(c) the adverse effect of the taking of the lands by the company on the remaining lands of an owner;

(d) the nuisance, inconvenience and noise that may reasonably be expected to be caused by or arise from or in connection with the operations of the company;

(e) the damage to lands in the area of the lands taken by the company that might reasonably be expected to be caused by the operations of the company:

(f) loss of or damage to livestock or other personal property affected by the operations of the company;

(g) any special difficulties in relocation of an owner of his property; and

(h) such other factors as the Committee considers proper in the circumstances.

The Arbitration Committee may direct the company to pay interest on the amount of compensation awarded, and the rate of interest is to be "at the lowest rate of interest quoted by chartered banks to the most creditworthy borrowers for prime business loans, as determined and published by the Bank of Canada for [the relevant time]". ${ }^{259}$ Just exactly what is intended by this section seems uncertain. Chartered banks may have different prime lending rates, and even branches of the same bank may at different times have different rates. What happens in the event that the Bank of Canada does not make the determination contemplated in the section, or does not publish it?

Costs are awarded automatically to the landowner in the event that the Committee's award exceeds 85 percent of the amount of compensation offered by the company, so long as such costs are found by the Committee to

$\begin{array}{ll}253 . & I d, \text { s. } 75(1) . \\ 254 . & I d, \text { s. 75(2). } \\ 255 . & I d ., \text { s. 75(3). } \\ 256 . & I d, \text { s. 75.1. } \\ 257 . & I d, \text { s. 75.14. } \\ 258 . & I d ., \text { s. 75.19. } \\ 259 . & I d, \text { s. 74.2(3). }\end{array}$


have been reasonably incurred. Even if the 85 percent threshold has not been reached, the company may be liable for costs, as they are then in the discretion of the Committee, but the Committee may require the owner to pay them as well. ${ }^{260}$

The Arbitration Committee has the power to review, rescind, amend or substitute a decision and can even review the amount of compensation awarded if the original order contemplates that such a review will take place. ${ }^{281}$ There is an appeal on a question of law or jurisdiction to the Federal Court, Trial Division, and the appeal must be taken within thirty days after the day on which the decision, order or direction is made, given or issued, unless there are special circumstances for extending the time. ${ }^{262}$

\section{B. The Select Legislative Committee on Surface Rights}

The Select Legislative Committee on Surface Rights in Alberta has heard submissions from the resource and agricultural industries, and is expected to report to the Legislature in early 1982. The report will likely form the basis for future legislative changes in the area.

The committee's terms of reference were as follows:

A. Review existing and proposed methods of expediting claims directed to the Alberta Surface Rights Board.

B. Examine the role of appointed surface rights mediators and make recommendations concerning their terms of reference and appropriate professional qualifications in the context of surface rights mediation.

C. Review present levels of compensation to landowners and make recommendations by which these levels might be adjusted.

D. Examine the role of landmen in surface rights mediations and make recommendations concerning their terms of reference and appropriate professional qualifications.

E. Review the Alberta Surface Rights Act and identify sections requiring amendments and make recommendations.

The writers have reviewed many of the submissions made by the resource industry, landmen, farmers and lawyers to the Select Committee, including the submission of the Canadian Association of Petroleum Landmen. As a result of that review, the authors predict the following changes:

1. The industry will be forced to locate well-sites in a manner which is more advantageous to farming operations, with such locations generally being on fence lines and not in the centre of interior legal subdivisions as has traditionally been the practice. Such a requirement is already in existence in the Peace River area of the Province. The industry could well be required to utilize directional drilling techniques.

2. Annual rental will be paid on pipelines.

3. The review period for annual compensation will be shortened from five to three years.

260. Id., s. 75.21.

261. Id., s. 75.22(2).

262. Id, s. 75.23 . 
4. There will be an information bank established and the industry will be required (much like it is now required to do in Saskatchewan) to provide copies of agreements with the Government, and the same will be available to the public.

5. Annual compensation will become reviewable with respect to leases and orders which were in existence prior to 1972.

6. Mediation will become part of the process with government appointed mediators making recommendations to the industry representatives and the landowners. The mediators' recommendations will not be binding.

7. The professional status of landmen will be recognized and a person will have to meet certain standards of competence in order to be entitled to a license under The Land Agents Licensing Act.

8. Legislation will be passed similar to s. 55 of The Expropriation Act that residual value may be ignored.

9. Political realities will ensure that the present policy of awarding compensation beyond fair market value for the surface rights required by the resource industry will continue. 